Research, part of a Special Feature on Archetype Analysis in Sustainability Research

\title{
Archetypical pathways of direct and indirect land-use change caused by Cambodia's economic land concessions
}

\author{
Nicholas R. Magliocca $^{1}$, Quy Van Khuc ${ }^{1}, \underline{\text { Evan A. Ellicott }}^{2}$ and Ariane de Bremond $^{2,3}$
}

\begin{abstract}
In the global South, a rush of large-scale land acquisitions (LSLAs) is occurring by governments and transnational and domestic investors seeking to secure access to land in developing countries to produce food, biofuels, and other agricultural commodities. Complex interactions between regional and global market dynamics and local institutional, socioeconomic, and agro-ecological conditions can lead to widely varying causal processes, land-use change (LUC), and socioeconomic and environmental outcomes. Systematic understanding of how characteristics of LSLAs across multiple social and environmental contexts produce spillover effects on local communities, ranging from employment opportunities to displacement and indirect land-use change (iLUC), is lacking. We conceptualize agricultural commodity production and land-acquisition processes associated with LSLAs as catalyzing causal pathways of direct and indirect land-use changes. Using the case of economic land concessions (ELCs) in Cambodia, we employed a novel synthesis research approach combining remote sensing, spatio-temporal statistics, and case study meta-analysis to construct archetypical pathways of the causes, timing, and consequences of ELC-driven land change. Archetypical pathways generally diverged based on specialized or flex commodity crops and rates of direct LUC, and rapid rates of direct LUC tended to cause displacement and iLUC. In contrast, ELCs producing commodity crops associated with more gradual land-use change and/or organized local resistance lead to less iLUC. Systematic knowledge generated through synthesis of local causes and consequences of LSLA-driven land change is now possible and needed to better address the direct and indirect consequences of LSLAs for commodity crop production.
\end{abstract}

Key Words: deforestation; matching; mixed methods; survival analysis; triangulation

\section{INTRODUCTION}

The last decade brought a sharp increase in large-scale land acquisitions (LSLAs) in the global south as governments and transnational and domestic investors sought to secure access to land to produce food, biofuels, and other agricultural commodities (Anseeuw et al. 2013, Messerli et al. 2014, Gironde et al. 2016). Large-scale land acquisitions often result in large tracts of land being converted from forest or low-intensity smallholder land use to large-scale agriculture (Messerli et al. 2014), which can significantly alter local water budgets, increase greenhouse gas (GHG) emissions, and compromise ecosystem services (Balehegn 2015, Breu et al. 2016, Carter et al. 2017). Large-scale land acquisitions may also be strategic responses to energy and water crises and food price spikes by governments, transnational firms, or domestic investors (Zoomers 2010, Baird 2014), symptomatic of an increasingly globalized and teleconnected world system. Such responses disproportionately affect rural, poor, and/or indigenous communities with precarious land tenure (Borras and Franco 2011, Baird 2017, Dell'Angelo et al. 2017). The result is often the displacement of land from smallscale production in regions already facing food security issues and placing it in the hands of well-capitalized investors that may not use it to produce food when such issues arise. The potential for future waves of LSLAs in response to either environmental or political disruptions of economic relations (Seekell et al. 2017) demands consideration of the multiple pathways through which LSLAs can support or jeopardize local socioeconomic and environmental sustainability.

Comparative studies and meta-analyses have described common national-level factors that make particular countries favorable targets for transnational investors, and the myriad of social and environmental consequences at the local level that are direct results of LSLAs (Messerli et al. 2014, Oberlack et al. 2016, Vandergeten et al. 2016, Carter et al. 2017, Dell'Angelo et al. 2017). More elusive, however, has been an understanding of the causal chains of events linking the occurrence of LSLAs, land-use change (LUC) resulting when LSLAs begin production (i.e., implementation), and associated socioeconomic impacts and indirect land-use change (iLUC) in surrounding communities. Currently, information about LUC associated with specific LSLAs is fragmented across the literature in numerous case studies, and causal inference about their timing and associated LUC is challenged because of the multiscale nature of LSLAs (e.g., Eckert et al. 2016). Importantly, the unit of analysis must be consistent with the phenomenon of interest, in the case of direct LUC and iLUC, high resolution and temporally rich information is needed (Eckert et al. 2016). For example, Özdoğan et al. (2018) combined remote sensing and advocacy-based field work to examine the social and environmental impacts of rubber concessions in Laos' Champasak Province. Although indicative of the level of detail needed to unpack the LSLA phenomenon, additional innovation is needed to undertake causal inference across local, national, and global scales. Bringing multiscale, heterogeneous data sources together, including existing case study literature, dense remote sensing time series, historical policy analysis, and commodity trade data, will enable a fuller understanding of when and where future LSLAs might occur and the likely scope of social and environmental consequences (Scoones et al. 2013, Messerli et al. 2014, Oberlack et al. 2016).

We present the first attempt at such a synthesis to integrate multiple, heterogeneous data sources and methods to produce bounded generalizations of the processes and outcome of LSLAs in Cambodia. Our aim is to construct archetypical pathways causally linking fluctuations in global commodity prices, the timing of

${ }^{1}$ Department of Geography, University of Alabama, Tuscaloosa, Alabama, USA, ${ }^{2}$ Department of Geographical Sciences, University of Maryland, College Park, Maryland, USA, ${ }^{3}$ Global Land Programme, Centre for Development and Environment (CDE), University of Bern, Bern, Switzerland 
LSLA establishment, factors influencing whether deforestation occurred (or not) within LSLAs, and resulting socioeconomic impacts leading to (or not) iLUC. This study uses economic land concession (ELC) data from Cambodia to demonstrate the potential of this synthesis approach to produce systematic knowledge across multiple localized cases of LSLAs. Methodologically, this study advances mixed methods synthesis approaches by integrating survival analysis, propensity score matching, and qualitative comparative analysis (QCA). More broadly, our study contributes to the development of middlerange theories of commodity-driven livelihood and land-use change (Magliocca et al. 2018, Meyfroidt et al. 2018).

\section{BACKGROUND}

\section{Global trends in large-scale land acquisitions (LSLAs)}

The rapid spread of LSLAs across the globe has been attributed to a range of drivers operating at multiple scales. Global factors include: rising food demand and prices; private sector expectations of higher agricultural and nonagricultural commodity prices for "boom" (e.g., rubber, coffee, cassava; Mahanty and Milne 2016, Hurni et al. 2017); government concerns about longer-term food and energy security (Scheidel et al. 2013); geopolitics (Oliveira 2016); capital market land speculation (Fairbairn 2014); potential future vulnerabilities of domestic food systems to climate change (Davis et al. 2015); the drive to secure ecosystem services (biodiversity, water, carbon sequestration; Rulli 2013, Breu et al. 2016, D’Odorico and Rulli 2017); and links to global trends in biofuel policies and the growth in production of flex crops (Scoones et al. 2013, Borras and Franco 2011).

At national and subnational levels, government development strategies and legal and regulatory regimes (Cotula 2012, Messerli et al. 2014), titling programs (Dwyer 2015), elite struggles (Keene et al. 2015), and even illicit activities (e.g., money laundering; Baird 2014) shape the particular ways that LSLAs are implemented and condition consequences for local livelihoods. Countries may further incentivize or otherwise create favorable policy environments to encourage foreign direct investment (FDI; Baird 2011, Carter et al. 2017) in hopes of improving investment in undercapitalized agricultural sectors and reaping positive spillover effects, such as access to improved techniques (if cultivating the same crop as smallholders), factor and outputs markets, and direct employment, as a means of broad-based poverty alleviation (Deininger and Xia 2016). Foreign direct investment has also been attracted to areas with high yield gaps, a large agricultural sector gross domestic product, and the perception of available land suitable for agriculture (Barney 2009, Carter et al. 2017).

Notwithstanding some evidence of positive spillover effects of LSLAs (Deininger and Xia 2016, Jung et al. 2019), mounting evidence suggests that LSLAs predominately bring negative social and environmental consequences to receiving areas. For example, Messerli et al. (2014) showed that $35 \%$ of georeferenced deals in the Land Matrix database, an open data initiative tracking LSLAs globally (Anseeuw et al. 2013, International Land Coalition et al. 2018), contained land-cover classes within LSLA boundaries consisting of mixed mosaics of vegetation and rain-fed cropland, indicating that the land was already being used for farming, while
$34 \%$ of deals had areas that overlapped with protected areas. Cambodia provides another example in which LSLAs (in the form of state-granted ELCs) have occurred in high-value forests, such as protected areas (Beauchamp et al. 2018), and indigenous areas in which the influx of land deals has been accompanied by inmigration, further hampering local capacity to access opportunities in trade, services, and jobs (Gironde and Peeters 2015).

\section{The Cambodian context}

Although the term "land acquisitions" is employed in the literature to refer to any type of land deal regardless of origin and type of investment, economic land concessions such as those that occur in Cambodia, specifically refer to a subset of LSLAs wherein the state grants land, in either concession or lease form, to foreign and national investors in areas that are categorized as pertaining to the state (Schönweger et al. 2012, Gironde and Portilla 2015). Economic land concessions in Cambodia have increased rapidly since the early 1990s when the postconflict nation rapidly transformed from a centrally planned to a market economy (Neef et al. 2013). By 1993, the Royal Government of Cambodia (RGC) created more than 30 forestry concession zones covering about 6.5 million hectares, privatizing those zones for exploitation (Mckenney et al. 2004). The Land Law of 2001 resulted in the subsequent conversion of these lands back to state property under a new legal category, "state public land" (Neef et al. 2013). Following a short period of enhanced forest control by the Cambodian Forest Administration, a new wave of land concessions followed Subdecree 146 on economic land concessions (Royal Government of Cambodia 2005) and a strong emphasis by the RGC on the promotion of agro-industrial plantations. The most recent estimate of the extent of land granted in ELCs is 2.05 million ha (ODC 2018), roughly equivalent to a third of Cambodia's agricultural land. Even though much concessional land remains underdeveloped, the annual forest loss contribution of ELCs that have begun production rose from $12.1 \%$ in 2001 to $27.0 \%$ in 2012 (Davis et al. 2015). Village census data showed that 277 villages, home to 213,000 people, fell within ELC boundaries with over 100 ELCs estimated to have been at least partially granted on indigenous lands (Subedi 2012). Following domestic and international pressures, a moratorium of all new ELCs was declared in 2012, but many new and emerging land disputes have yet to be resolved (Dwyer 2015, Milne 2015). Furthermore, anecdotal evidence suggests that additional forest loss resulting from displacement of local communities by ELCs may be common (Gironde and Peeters 2015, Baird and Fox 2015, Baird 2017, Beban et al. 2017, Fox et al. 2018), but the magnitude of iLUC's contribution to overall deforestation is unknown.

\section{CONCEPTUAL FRAMEWORK}

Agricultural commodity production for distant economies transforms the rural landscapes in which production takes place (DeFries et al. 2010). To investigate these global-to-local interactions, we adopt and adapt the conceptual framework of pathways for commodity crop expansion (Meyfroidt et al. 2014), which has been applied to study the multiple possible but conditionally bounded outcomes of increased commodity crop production. Their proposed framework imposes an overarching structure of a series of cause-effect relationships (i.e., causal 
Fig. 1. Conceptual framework for multiple pathways of large-scale land acquisitions (LSLA) initiated commodity crop expansion linked to direct land-use change (LUC) and associated cascade and/or displacement effects creating social and indirect LUC consequences. The colors of each of the boxes correspond with the objects of analyses described in Figure 2.

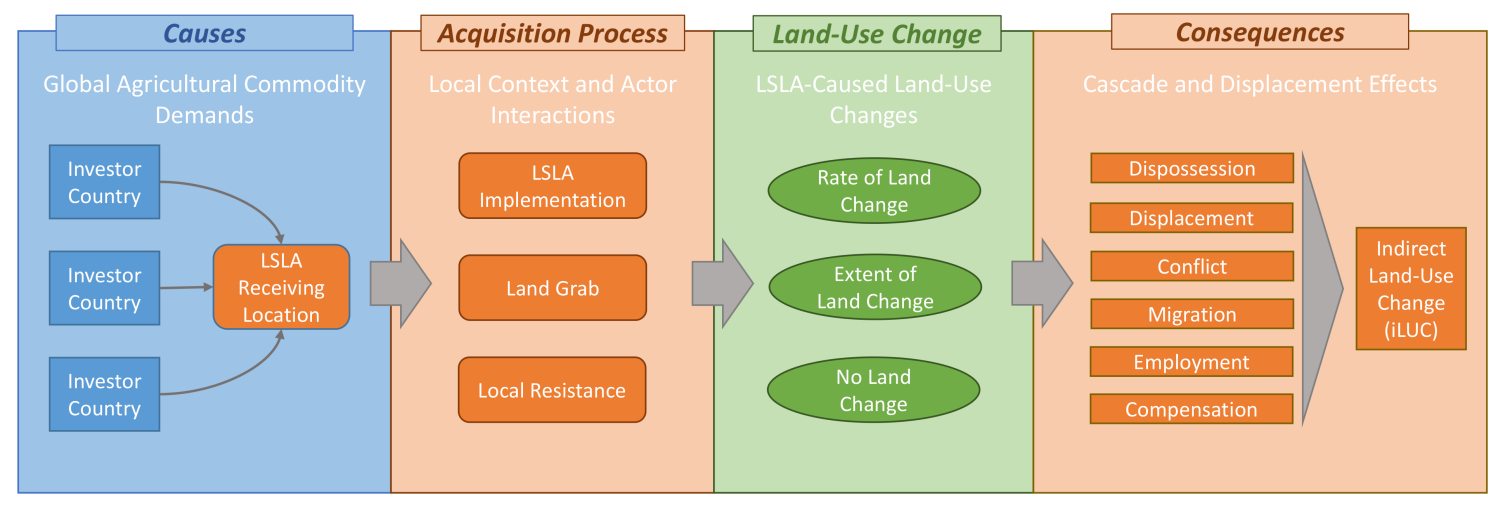

chains or pathways) leading to varying commodity crop expansion outcomes (e.g., agricultural intensification with land sparing; agricultural expansion into forests) with possible positive feedbacks and additional or indirect LUC. We adapt this framework with the broader concept of LSLAs to disentangle processes of direct and indirect LUC following the establishment and/or implementation of LSLAs.

Commodity crop pathways begin with the establishment of an LSLA, which initiates a causal chain of events leading to an array of social and LUC outcomes. Each pathway is defined by a combination of causal factors and/or processes: (1) the attributes of the LSLA (e.g., investor origin, characteristics of the commodity crop), (2) processes of land acquisition, (3) rate and extent of direct LUC associated with LSLA implementation (i.e., active production), and (4) the resulting cascade and/or displacement effects from the direct LUC producing varying combinations of social impacts that may or may not lead to iLUC. We define iLUC as LUC observed outside of the spatial extent of direct LUC associated with LSLA implementation (i.e., extent of planation or large-scale row crop production), undertaken by small-scale actors and occurring proximately in space and time to the establishment or implementation of an LSLA. Empirically, in the case of ELCs in Cambodia, we define spatial proximity as within the same commune as the ELC, and temporal proximity as occurring after ELC establishment or implementation (LUC occurring before those dates is excluded). Individual LSLAs can be described by a single pathway; and common, repeating pathways observed across the study region constitute an archetypical pathway (Fig. 1).

The unique attributes of an LSLA can lead to different pathways of social and LUC outcomes. Although the origin of the LSLA investor is important, particularly if there are substantial governance or political, cultural, and/or economic power differences between investor and receiving countries (Milne 2015, Beban et al. 2017, Beauchamp et al. 2018), we focus primarily on characteristics of the commodity crop. Local responses to the introduction of commodity-oriented agriculture depend on whether a given commodity crop has specialized or multiple uses. Multiple use commodity crops, or flex crops (Borras et al. 2016), such as cassava and sugar cane, can substitute for other commodities of the same type (i.e., food crop for food crop) or of different types (i.e., food crop for fuel crop; Wadhwa and Bakshi 2013), resulting in a relatively stable market demand. Furthermore, low capital-intensity crops, like cassava, are often a gateway crop (Mahanty and Milne 2016) for smallholders into commodity-oriented production because of characteristics of low agricultural inputs, easily cultivated on newly cleared land with minimal improvement, and relatively quick cropping cycle. These attributes also make these crops likely candidates for commodity crop production by smallholder through iLUC in proximity to or introduced by LSLAs. In contrast, specialized commodity crops do not easily substitute for other crops or only have a few specialized applications. In the case of rubber, for example, high oil prices can make synthetic rubber unprofitable for manufacturing value-added products like tires, and natural rubber can act as a substitute. In addition, specialized commodities, such as rubber, may have a longer cropping cycle (Mahanty and Milne 2016), which favors well-capitalized farmers that can weather variations in commodity prices.

The processes through which land is acquired for LSLAs are distinguished by the nature of interactions among investor, government, and local actors. The land-acquisition process articulated most often in the literature is that of the land grab (e.g., Cotula et al. 2009, Zoomers 2010, Borras and Franco 2011, Edelman et al. 2013, Dell'Angelo et al. 2017). Land grabs often entail political-economic means of dispossession of communal land, exploitation of informal or incomplete land titling of marginalized communities, and/or a lack of transparency in the concession-granting process. On the other end of the spectrum, there are various forms of resistance and conflict from local communities to LSLAs, including physical confrontation, preemptive land clearing, and legal action (Baird 2017), which impact subsequent implementation or abandonment of LSLAs and potential cascade and displacement effects. Beside these extremes, land acquired for other LSLAs can proceed without confrontation with and/or dispossession of local communities, although this appears less frequently in the literature. 
Both the nature of the LSLA and the land-acquisition process influence the rate (i.e., the time between establishment and implementation) and spatial extent of LUC associated with LSLAs, which can create, avoid, and/or mitigate indirect social, economic, and environmental impacts. Large-scale land acquisitions producing specialized boom crops, such as rubber, might have short lag times between establishment, land conversion, and implementation to capitalize on volatile commodity prices, often abruptly dispossessing and displacing local communities (Oldenburg and Neef 2014, Baird and Fox 2015). Alternatively, gradual progression from LSLA establishment to implementation may allow for negotiated resettlement, involvement of nongovernmental organizations (NGOs), or local communities to organize resistance (Gironde and Peeters 2015, Beban et al. 2017). The lag time between establishment and implementation may also reveal the intentions of investors, such as land speculation, when little or no direct LUC is observed.

Finally, all of the preceding factors and processes have the potential to create configurations of social impacts that create cascade and/or displacement effects (Lambin and Meyfroidt 2011) leading to iLUC. Impacts can range from direct employment to dispossession and displacement from land used for subsistence cultivation, which leads in some cases to social unrest and conflict (Oberlack et al. 2016, Dell'Angelo et al. 2017). Displacement effects occur when existing activities within newly established or implemented LSLA boundaries, e.g., smallholder agriculture, are relocated to adjacent or distal locations, often resulting in clearing of forest from land not previously used or occupied. Cascade effects include displacement effects, but also entail more complex social processes, such as inmigration or changing land-tenure arrangements, that are catalyzed by LSLA establishment or implementation and motivate iLUC for reasons beyond replacing displaced land use. Cascade and displacement effects can be complex and difficult to trace empirically. For example, iLUC may be caused by displaced local communities seeking to maintain their agricultural livelihoods, but also by inmigrants attracted by employment, speculative, or exploitive opportunities presented by LSLA establishment (Baird and Fox 2015, Fox et al. 2018). In this study, we are concerned with the localized iLUC that occurs within the immediate vicinity of and that can be directly attributed to LSLAs. Although there can be regional- or global-scale indirect impacts from localized LSLAs, i.e., rebound or remittance effects (Lambin and Meyfroidt 2011), or displacement of the agricultural frontier (Arima et al. 2011), such distal interactions are difficult to measure without clear sending and receiving areas.

\section{METHODOLOGY}

\section{Framework for archetype analysis toward the development of middle-range theory}

The analytical methods and study design were chosen with the goal of constructing archetypical pathways as a foundation for future development of middle-range theory. Archetype analysis is a comparative approach that seeks to identify a set of recurring, theoretically grounded building blocks of factors and/or processes that can be combined in various ways to simply describe or infer causal mechanisms from a population of cases (Oberlack et al. this issue). Middle-range theory is defined as "contextual generalizations that describe chains of causal mechanisms explaining a well-bounded range of phenomena, as well as the conditions that trigger, enable, or prevent these causal chains" (Meyfroidt et al. 2018:53). In providing a path toward generalized knowledge of land systems, middle-range theories provide knowledge that can support progress toward sustainable socialecological systems (Meyfroidt et al. 2018).

Developing middle-range theory entails a process of gathering and analyzing observations from a specific phenomenon from which generalized explanations of similar phenomena are built. These are then applied to and tested on other phenomena sharing characteristics, contextual conditions, and/or causal mechanisms (Meyfroidt et al. 2018). Using the commodity pathways concept, we identified repeating spatial and temporal patterns of causal events that were constructed into archetypical pathways to describe all ELCs in Cambodia. In future work, archetypical pathways can then be empirically tested against a broader array of LSLAs within the mainland Southeast Asia region and beyond to develop middle-range theory.

The archetype concept and methodology in sustainability research mainly originates from the concept of system archetypes in the field of system dynamics. System archetypes were used to characterize generic structures and behaviors of systems (Senge 1990, Wolstenholme 2003, 2004) and have been employed to represent typical causal linkages that reappear across many cases (Bennett et al. 2005). Archetype analysis has recently proliferated in sustainability research (Oberlack et al. this issue) with an increasing portfolio of methods (Sietz, Frey, Roggero et al., unpublished manuscript) and a unique set of challenges (Eisenack et al. 2019). Increasingly, archetype analyses are being employed across a range of literatures and fields of study, including land system science (Václavík et al. 2013, Levers et al. 2018), governance and institutional change (Oberlack et al. 2016), and global change (Sietz 2014). Our work builds on early attempts to link spatial patterns of land acquisitions with implementation processes (Messerli et al. 2014, Oberlack et al. 2016, Dell'Angelo et al. 2017, 2018), pushing the frontiers of archetype analysis by constructing pathways of direct and indirect ELC land-use change and socioeconomic consequences that are both spatially and temporally explicit (Sietz, Frey, Roggero et al., unpublished manuscript).

Although the causes (Messerli et al. 2014), direct LUCs (Davis et al. 2015), and socioeconomic consequences of LSLAs have been investigated in various contexts (e.g., Baird 2017, Dell'Angelo et al. 2017, Fox et al. 2018), they have yet to be systematically synthesized in support of theory of LSLA-caused land-system change. Because of the fragmented and/or partial nature of knowledge about LSLAs, the wide variety of conditions under which LSLAs occur, and the myriad of social and environmental outcomes associated with LSLAs, developing middle-range rather than grand theory is a more pragmatic approach to theorizing LSLA-caused land-system change (Magliocca et al. 2018). Two features of this research position it to contribute to the development of middle-range theory. First, although the generalized knowledge produced through this synthesis approach is applicable across Cambodia (and potentially beyond), the level of the analysis matches that of the localized processes leading to LUC. Second, and enabled by the previous point, we link findings 
from various methods over space and time to assemble causal pathways (Meyfroidt 2016) that provide mechanistic explanations of observed outcomes, which can be more reliably applied as archetypical pathways beyond the conditions of direct observation than correlative explanations alone (Magliocca et al. 2018).

Construction of archetypical pathways relied on mixed methods triangulation (Morse 1991, Mertens and Hesse-Biber 2012) with each method attending to different aspects of ELCs: global commodity market signals, spatial patterns of LUC, timing of ELC establishment and implementation, or localized processes of land acquisition and social impacts. We linked the findings from all methods across space and time to construct complete causal pathways of the timing of ELCs, direct and indirect LUC, and associated socioeconomic consequences. These linkages, or inferential bridges, entailed using qualitative findings from one analysis to structure quantitative data for another and vice versa, such that inferences with one method would not be possible without inferences made by another. Specifically, we conducted QCA to extract rich but bounded information from case studies $(\mathrm{n}=30)$ about the local processes of land acquisition, socioeconomic impacts, and instances of direct and indirect LUC associated with specific ELCs. Direct and indirect LUC was quantified from remote sensing for all ELCs $(\mathrm{n}=210)$ in Cambodia (Fig. 2). Local land-acquisition process information was linked with observed LUC using causal inference methods to detect statistically significant patterns in the timing, location, and spatial extent of direct and indirect LUC among stratifications (i.e., types of ELCs with similar characteristics) based on ELC characteristics, such as investor country, developing company, and intended crop. Triangulating such patterns and cross-checking the robustness of ELC strata with multiple, independent datasets provided stronger inference than would have been possible with any single method alone. Detecting significant differences among ELC strata across multiple analyses supported extrapolation of causal mechanisms identified for ELCs described from case studies to other ELCs of the same strata but without direct case study observations.

\section{Data}

Economic land concession data was available from Open Development Cambodia (ODC 2018), a nongovernmental organization that provides freely available geospatial data about Cambodia's economic, social, and environmental change. Open Development Cambodia currently contains over 200 ELCs with polygon features representing the spatial location of a deal (Fig. 3 ). Economic land concessions used in our analysis occurred since the year 2000 and included the contract year (or government subdecree if the contract date was not provided), intended crop, and status of the ELC (i.e., no change, downsized, revoked). A 500-meter buffer was added around the boundaries of all ELCs to capture direct LUC that exceeded the predefined concession boundaries. Any LUC that occurred within the buffer was considered direct LUC. Consequently, this produced conservative estimates of iLUC defined as any LUC occurring outside of the buffer and in adjacent communes. The ELCs from ODC were crossvalidated with the Land Matrix database to insure there were no gaps; however, because the Land Matrix often pulls its information from ODC, we did not expect, nor found, any discrepancies. We recognize that the Land Matrix does not capture all land acquisitions and the data provided reflect, in part, their partnership with regional and local organizations. In the case of Cambodia, however, the land concession data are quite robust because they were gathered by ODC as part of a regional open-data initiative.

A suite of geospatial and socioeconomic data was also collected for use in multiple statistical analyses. A full list and description are provided in Table 1. Socioeconomic and agriculture census

Fig. 2. Logic of generalization for archetype analysis. Triangulation among mixed methods built inferential bridges between rich but limited information from case studies of select economic land concessions (ELCs; $\mathrm{n}=30$ ) and coarse but comprehensive $(\mathrm{n}=210)$ information from remote sensing and statistical analysis on all ELCs in Cambodia. Note: ODC = Open Development Cambodia; LSLA = large-scale land acquisitions.

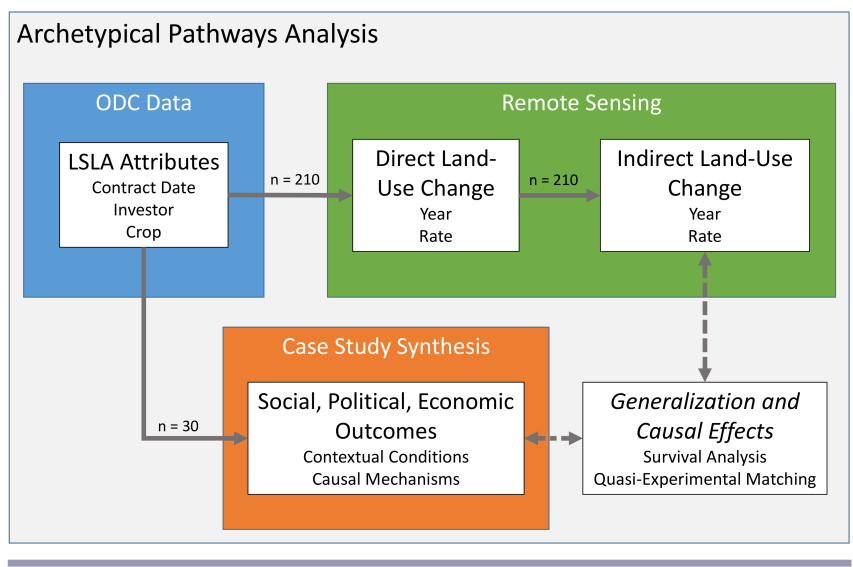

Fig. 3. Map of all economic land concessions (ELCs) provided in the Open Development Cambodia (ODC) database (blue) and ELCs used in the cross-site comparison highlighted (yellow). The background data layer shows \% forest cover in the year 2000 .

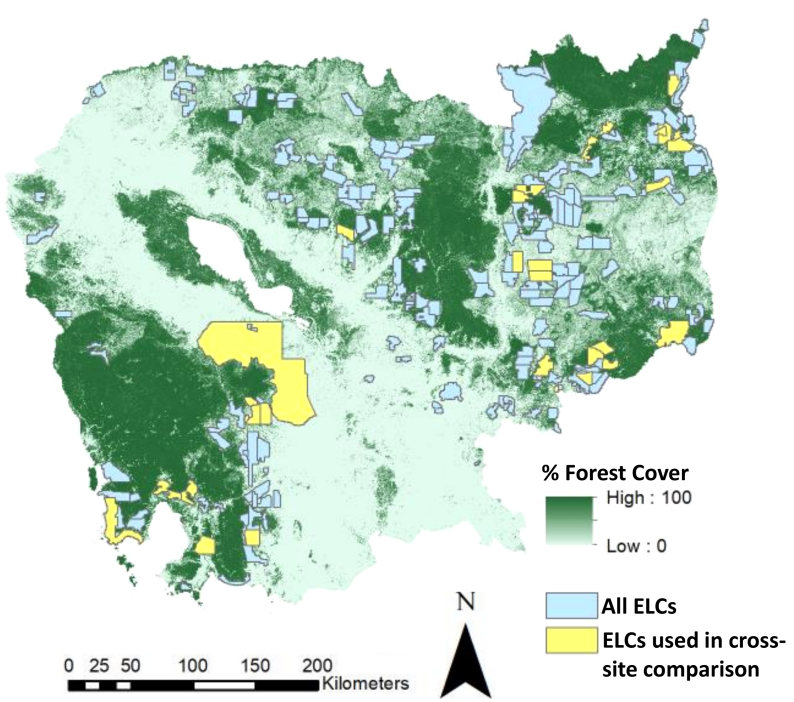


Table 1. Descriptions of independent variables used in one or more analyses. Note: ELC = economic land concessions.

\begin{tabular}{|c|c|c|c|}
\hline \multicolumn{2}{|l|}{ Independent Variables } & \multirow[b]{2}{*}{ Units } & \multirow[b]{2}{*}{ Source } \\
\hline Name & Description & & \\
\hline \multicolumn{4}{|l|}{ Time-Independent } \\
\hline Median Slope & $\begin{array}{l}\text { Median slope calculated from high resolution }(\sim 30 \mathrm{~m}) \text { topographic } \\
\text { data from the ASTER Global DEM }\end{array}$ & $\begin{array}{l}\text { aggregated to ELC or } \\
\text { commune boundary }\end{array}$ & (NASA and METI 2011) \\
\hline Market Influence Index & $\begin{array}{l}\text { Accessibility to market locations (travel time to cities of }>50,000 \mathrm{ppl} \text { ) } \\
\text { and national level gross domestic product (purchasing power parity) }\end{array}$ & index value & (Verburg et al. 2011) \\
\hline Poverty Rate & Percent of census population below poverty line & $\%$ & (ODC 2018) \\
\hline Cassava Yield & Average cassava yield per year & metric & (ODC 2018) \\
\hline Commune Area & Size of commune (administrative unit) & hectares & (ODC 2018) \\
\hline Rice Ratio & Ratio of rice field size to commune size & $\%$ & (ODC 2018) \\
\hline Cassava Area & Commune-level land area for cassava production & $\%$ & (ODC 2018) \\
\hline Maize Area & Commune-level land area for maize production & $\%$ & (ODC 2018) \\
\hline Cashew Area & Commune-level land area for cashew production & $\%$ & (ODC 2018) \\
\hline \multicolumn{4}{|c|}{ Time-Dependent (annual values for 2000 to 2015 ) } \\
\hline Population Density & Annual population density mapping product at $\sim 1 \mathrm{~km}$ resolution & ppl km ${ }^{-1}$ & (ORNL 2017) \\
\hline Total Population & $\begin{array}{l}\text { Total population derived from population density and aggregated to } \\
\text { the commune level }\end{array}$ & $\mathrm{ppl}$ & (ORNL 2017) \\
\hline Forest Cover & Percent forest cover & $30 \mathrm{~m}$ & (Hansen et al. 2013) \\
\hline $\begin{array}{l}\text { Global Commodity } \\
\text { Prices }\end{array}$ & $\begin{array}{l}\text { Global commodity prices for natural rubber, cassava, maize, hard logs } \\
\text { (e.g., teak), and sugar }\end{array}$ & $\$ \mathrm{~kg}^{-1}$ & (Index Mundi 2018) \\
\hline $\begin{array}{l}\text { Time Since ELC Land } \\
\text { Conversion }\end{array}$ & Years since threshold forest loss year within ELC boundary & years & $\begin{array}{l}\text { Derived from ELC } \\
\text { information (ODC 2018) }\end{array}$ \\
\hline
\end{tabular}

data reported at the commune level, the next largest administrative unit above villages, was provided for 2008 by ODC. Cross-sectional (i.e., time-independent) data collected in raster form for continuous variables, such as slope and market influence, were spatially intersected with and aggregated to commune administrative boundaries. Time series (i.e., time-dependent) data were acquired for 2000-2015 from sources outside of ODC (Table 1) and harmonized to coincide with commune administrative boundaries. Lagged and leading variables were created at intervals of one and two years for all time-dependent variables as additional explanatory variables and robustness checks for any time-sensitive correlations, respectively.

\section{Empirical methods}

The suite of methods used are described in Table 2. In the case of Cambodia, we observed direct and indirect LUC related to ELCs as forest loss. Although the vast majority of ELCs were observed in forested areas, cases may exist in which LUC could occur through different crop types or intensification, but we did not account for such changes. We used the Hansen et al. (2013) Global Forest Change (GFC) dataset for our study period of 2000-2015. This dataset was chosen because the vast majority of ELCs in Cambodia have occurred in forested areas, defined by Hansen et al. (2013) as vegetation taller than five meters. We used the estimate of percentage tree cover in each $30 \mathrm{~m}$ cell for the year 2000 and annual forest cover loss estimates, defined as standreplacement change from a forest to nonforest state, in subsequent years. Only one snapshot of socioeconomic data was available during the study period, which did not allow inference about changes in agricultural productivity, well-being, or formal employment before and after ELC establishment. Similarly, we could only assess the immediate and spatially proximate impacts of ELCs on adjacent communities in the form of reported dispossession, displacement, resistance, employment, migration, and iLUC.
Forest-cover change was used to define the dependent variable in all but one of our statistical analyses (Table 2). For each analysis, the year in which a threshold of forest loss was exceeded (i.e., threshold loss year) was calculated for all raster cells within an ELC boundary or ELC-adjacent commune boundary depending on the analysis. Threshold loss year was defined as the first year in which the total cumulative or year-to-year forest loss exceeded the threshold, whichever came first. The majority forest loss year (i.e., more frequent) was also explored but proved to be an inconsistent indicator of ELC-related forest loss. For analyses of direct LUC within ELC boundaries, the forest-loss threshold was assumed to be $10 \%$. A value of $10 \%$ was chosen because smallholder land use was unlikely to achieve this rate of annual forest loss, whereas this rate was observed for large-scale ind ustrial and plantation agriculture. We tested these assumptions with visual inspection of forest-loss rates for ELCs with known high spatial accuracy and confidence in ELC information (crossvalidated against Land Matrix data). For analyses of iLUC in ELC-adjacent communes, we conducted a sensitivity analysis of $10 \%, 7.5 \%, 5 \%$, and $3 \%$ threshold values. A value of $7.5 \%$ was chosen based on QCA coverage and consistency results and corroborated with remote sensing analyses and case study narratives (see section Appendix 1, A1.5). A possible confounding effect for attributing iLUC at the commune level to specific ELCs was the possibility of multiple ELCs occurring within the same commune at different times throughout the study period. We addressed this issue by removing any areas contained within ELC boundaries from the forest-cover data from the year of an ELC contract to the end of the study period.

\section{Propensity score matching}

A quasi-experimental matching approach was used to estimate the average treatment effect on the treated (ATT) testing whether communes containing an ELC were more likely to experience iLUC in the form of spillover deforestation than otherwise could 
Table 2. Description of analytical methods and their dependent variables used to construct archetypical pathways of direct and indirect land-use changes (LUC) and socioeconomic consequences of economic land concessions (ELCs).

\begin{tabular}{|c|c|c|c|c|}
\hline & $\begin{array}{l}\text { Timing of ELC } \\
\text { Occurrence }\end{array}$ & Timing of Direct LUC & ELC-driven iLUC & Socioeconomic Consequences \\
\hline Statistical Method & Survival analysis & Survival analysis & Propensity score matching & Qualitative comparative analysis (QCA) \\
\hline $\begin{array}{l}\text { At Risk/Study } \\
\text { Period }\end{array}$ & 2000 to 2015 & $\begin{array}{l}\text { Contract or subdecree year } \\
\text { to } 2015\end{array}$ & 2000 to 2015 & 2000 to 2015 \\
\hline Unit of Analysis & ELC & ELC & Commune & ELC and affected local communities \\
\hline Dependent Variable & Time to ELC signing & $\begin{array}{l}\text { Time to threshold forest } \\
\text { loss year }\end{array}$ & Forest loss $\geq$ threshold loss & iLUC \\
\hline $\begin{array}{l}\text { Dependent Variable } \\
\text { Description }\end{array}$ & $\begin{array}{l}\text { Either year of contract } \\
\text { or government subdecree } \\
\text { granting ELC }\end{array}$ & $\begin{array}{l}\text { First year with } 10 \% \text { of } \\
\text { total forest cover lost or } \\
\text { first year with year-to-year } \\
10 \% \text { loss, whichever comes } \\
\text { first }\end{array}$ & $\begin{array}{l}\text { Binary variable indicating } \\
\text { whether } 7.5 \% \text { threshold } \\
\text { forest loss exceeded }\end{array}$ & $\begin{array}{l}\text { Binary variable for presence/absence of } \\
\text { iLUC, validated by remote sensing and } \\
\text { coded with dispossession, displacement, } \\
\text { resistance, employment, and migration }\end{array}$ \\
\hline
\end{tabular}

be attributed to "background" land-use trends. Communes were chosen as the unit of analysis to be consistent with available socioeconomic data. Communes were categorized as treated (those containing an ELC) and control (nonadjacent to an ELC) to estimate the effect of ELCs on the likelihood of LUC or iLUC occurring.

Treatment and control communes were paired using propensity score matching to control for commune characteristics that likely influenced deforestation: rice ratio, slope, market influence, population density, and percent tree cover at the start of the period (2000; Table 1). A probit regression model estimated propensity scores for each commune giving the probability that a commune was in the treatment group given commune characteristics (Rosenbaum and Rubin 1983). Each ELC-adjacent commune (treatment) was matched one-to-one with a non-ELC-adjacent commune (control) with the most similar propensity score value clustered geographically at the provincial level.

Quality of matching was evaluated with median of standardized biases (MSB) estimated for each commune characteristic. A clear threshold for acceptable MSB does not exist, but we adopted a statistic less than $10 \%$ as an indication of quality matching (Caliendo and Kopeinig 2008, Blackman et al. 2015). Table A1.1 (Appendix 1) shows the results of the MSB assessment comparing propensity score matching with the common alternative approach of covariate matching based on Mahalanobis distance. Propensity score matching outperformed covariate matching, produced paired treatment and control communes with sufficiently low MSB, and reduced variations in paired treatment and control covariate means.

Additionally, paired treatment and control communes were stratified according to the reported ELC crop, rate of land conversion derived from the remote sensing analysis, and amount of provincial land area in ELCs. Stratifications were chosen based on insights from case studies, such as differential effects based on commodities (Baird 2010, Milne 2015), displacement associated with rapid ELC implementation (Baird 2017), and compounded effects of multiple ELCs in the same area (Oldenburg and Neef 2014, Baird and Fox 2015). The robustness of stratified groups was checked with tests of statistically significant differences in ATT and survival probability during the matching and survival analyses, respectively. Stratification balance was assessed by comparing sample means for each matching covariate (Caliendo and Kopeinig 2008, Blackman et al. 2015). No statistical differences between sample means of stratified treatment and control pairs were found (see Appendix 1, A1.2), which also reinforced the MSB findings of robust matching using propensity scores. We also calculated Rosenbaum bounds (Keele 2010) to check for sensitivity to unobserved factors that might bias selection into the treatment group (Rosenbaum and Rubin 1983, DiPrete and Gangl 2004, Blackman et al. 2015). Results suggested that our findings would remain significant even with matched pairs differing in their odds of treatment by as much as $30 \%$ (see Appendix 1, A1.3).

\section{Survival analysis}

Survival analysis was conducted to estimate potential causal effects of local conditions and regional/global market signals on the timing of ELC occurrence and direct LUC within ELC boundaries. Survival analysis, also known as duration analysis or hazard modeling, estimates the time-varying probability of transition between two states (Vance and Geoghegan 2002, An and Brown 2008, Wang et al. 2013). In this case, the transitions of interest occurring within the boundaries of known ELCs were between (1) existing land rights to economic concession (i.e., ELC occurrence reported as year of contract signing or government subdecree) and (2) forested to large-scale deforested (i.e., direct LUC). Unlike logistic regression, which does not effectively account for differences in the change of states at different points in the study period (Wang et al. 2013), survival analysis accounts for the effects of time-dependent (i.e., varying) covariates before and after a state transition relative to a base hazard rate. This makes survival analysis particularly well-suited for establishing the sequence of events leading to a state change and for assembling causal chains or pathways of land change and its consequences.

A fixed effect, stepwise regression was used to estimate survival probability for each ELC strata (Table 2) given the influence of all time-independent and time-dependent variables listed in Table 1. Based on the known influence of boom commodity crops in Southeast Asia (Mahanty and Milne 2016, Hurni et al. 2017) and qualitative evidence from case studies, ELCs were stratified by crop group. To ensure that crop strata were statistically meaningful, pairwise log-likelihood tests were performed to avoid overspecification. Comparisons of individual models were 
Table 3. Variable definitions and coding used for the cross-site comparison of case studies. Note: QCA = qualitative comparative analysis; ELC = economic land concessions; LSLA = large-scale land acquisitions.

\begin{tabular}{|c|c|c|c|}
\hline Variable & Code & fQCA Code & Definition \\
\hline \multirow[t]{4}{*}{ Conflict } & Direct & 1 & $\begin{array}{l}\text { Evidence of direct confrontation between ELC and community. Examples include reported land } \\
\text { disputes (LICAHDO), retaking or stopping use of LSLA land through force or threat of force }\end{array}$ \\
\hline & Indirect & 0.5 & $\begin{array}{l}\text { Evidence of political, legal, or otherwise nonphysical contestation of ELC by community } \\
\text { members. For example, a more conflictual livelihood context (sensu Oberlack et al. 2016), } \\
\text { contested compensation, political advocacy }\end{array}$ \\
\hline & Both & 1 & Some combination of direct and indirect conflict \\
\hline & None & 0 & No description of conflict provided \\
\hline Dispossess & & 1 or 0 & Dispossession of community land and/or access to natural resources as a result of LSLA \\
\hline Compensate & & 1 or 0 & Some form of individual compensation described, for example monetary or land exchange \\
\hline \multirow[t]{2}{*}{ Employment } & Full or Partial & 1 & At least some local community members employed in activities related to LSLA \\
\hline & None & 0 & No employment opportunities offered through LSLA \\
\hline Displace & & 1 or 0 & $\begin{array}{l}\text { Description of physical community displacement and/or out-migration resulting from LSLA ( } 1 / 0 \\
\text { for yes/no) }\end{array}$ \\
\hline Immigration & & 1 or 0 & LSLA has resulted in in-migration, usually from migrants seeking employment ( $1 / 0$ for yes/no) \\
\hline \multirow[t]{2}{*}{ ELC direct LUC } & Rapid & 1 & $\begin{array}{l}\text { Threshold deforestation detected } \leq 3 \text { years after ELC occurrence (i.e., year of contract signing of } \\
\text { government subdecree) }\end{array}$ \\
\hline & $\begin{array}{l}\text { Gradual or No } \\
\text { Change }\end{array}$ & 0 & \\
\hline \multirow[t]{2}{*}{ ELC crop } & Rubber & 1 & Reported intended crop of ELC was rubber \\
\hline & Other & 0 & Reported intended crop of ELC was cassava, sugar, cashews, oil palm, teak, or unknown \\
\hline
\end{tabular}

conducted to test the null hypothesis that survival probability between two groups was the same. If the null hypothesis was not rejected, then the two most similar crop strata were combined and the analysis repeated until all strata had statistically different survival probabilities. Finally, robustness checks were performed with one- and two-year leading time-dependent variables to rule out spurious correlations. For both leading times, only the ELC dummy variable (which was time-independent) was statistically significant, indicating that the significant relationships found with time-dependent variables hypothesized to influence subsequent ELC occurrence or associated land change, such as commodity prices, were meaningful.

Cross-site comparison of case studies and qualitative comparative analysis (QCA)

A cross-site comparison of case studies reporting on specific ELCs was conducted using QCA to identify common processes of ELC establishment and land conversion leading to various socioeconomic and land-use change outcomes. An initial search of the peer-reviewed and grey literatures was conducted in Web of Science and Google Scholar using the search parameters "Cambodia AND large-scale land acquisitions OR economic land concessions OR land grab". Additional sources were located through snowball sampling of reference lists. Because of data limitations, such as incomparable or inconsistent reporting of ELC characteristics or local responses to ELCs (Edelman 2013, Verkoren and Ngin 2017), case study comparisons could not be as comprehensive nor quantitatively rigorous as a meta-analysis (Magliocca et al. 2015). To assemble the most comparable case collection possible, case studies had to meet the following criteria:

- Provide sufficient geographic information at the subprovincial level to link to spatially explicit boundaries of specific ELCs reported in ODC records. Relevant geographic information ranged from georeferenced maps to intext descriptions of approximate locations.
- Report on an ELC meeting the definition of a large-scale land acquisition consistent with that of the Land Matrix (Anseeuw et al. 2013, International Land Coalition et al. 2018). Specifically, land deals that "entailed a transfer of rights to use, control or own agricultural land through sale, lease or concession; that cover 200 ha or larger; have been concluded since the year 2000".

- Report on an ELC intended for agriculture or timber extraction, excluding mining, urban land development, and conservation.

Linking ELCs reported in case studies to those in the ODC database was straightforward when georeferenced maps were provided. Lacking such spatially explicit information required triangulation of intext geographic location descriptions, name and country of origin of investor, and original ELC size, and then cross validating that information with what was reported in the ODC database. Applying these selection criteria resulted in a final collection of 15 case studies reporting 30 cases. Figure 3 shows the geographic distribution of analyzed ELC cases. A representativeness analysis (Schmill et al. 2014, Magliocca et al. 2018) was performed to assess whether the distributions of crop type, $\%$ forest cover in 2000, population density, and market influence observed in the collection of ELCs cases was biased relative to those observed for all ELCs in Cambodia. No statistical differences between the distributions of the ELCs in the case collection and those observed across all of Cambodia were detected using Fisher's Exact Test (see Appendix 1, A1.4).

Cases were iteratively coded based on the explanations for ELC occurrence and outcomes proposed in case study narratives. Intercoder reliability assessments were conducted and showed an initial agreement of $91 \%$. The coding strategy was revisited and refined until full intercoder agreement was achieved. The final set of case study variables (Table 3 ) was consistent with those cited in the emerging global narrative of the livelihood effects of LSLAs 
Table 4. Commune-level effect of ELC (economic land concessions) presence on iLUC (indirect land-use change; i.e., deforestation) based on the commodity crop produced (top), the rate of direct LUC within ELC boundaries (middle), and proportion of provincial land area in ELCs (bottom). Average treatment effects on the treated (ATT) are expressed as odds ratios. Note: $\mathrm{SE}=$ standard error.

\begin{tabular}{|c|c|c|c|c|c|c|}
\hline & $\begin{array}{c}\text { Paired } \\
\text { Obs. }\end{array}$ & $\begin{array}{l}\text { Total } \\
\text { Obs. }\end{array}$ & Treatment & Control & SE & $\mathrm{ATT}$ \\
\hline \multicolumn{7}{|l|}{$\overline{\mathrm{ELC} \mathrm{Crop}^{\dagger}}$} \\
\hline Crop Type 1 & 32 & 64 & -13.38 & -10.35 & 8.857 & $1.293 * *$ \\
\hline Crop Type 2 & 28 & 56 & -8.819 & -6.122 & 6.046 & 1.441 \\
\hline Crop Type 3 & 53 & 106 & -9.405 & -7.443 & 5.557 & 1.264 \\
\hline \multicolumn{7}{|l|}{ Direct LUC Rate } \\
\hline Rapid ( $\leq 3$ years) & 35 & 70 & -12.62 & -5.588 & 5.7725 & $1.259 * * *$ \\
\hline Gradual or No Change ( $>3$ years) & 78 & 156 & -9.381 & -8.992 & 6.4454 & 0.043 \\
\hline \multicolumn{7}{|l|}{ Provincial Area in ELC } \\
\hline Provinces with $<11 \%$ area in ELC & 30 & 60 & -6.979 & -7.695 & 8.544 & 0.9273 \\
\hline Provinces with $11-20 \%$ area in ELC & 48 & 96 & -9.942 & -7.703 & 4.718 & 1.260 \\
\hline Provinces with $>20 \%$ area in ELC & 35 & 70 & -13.91 & -8.47 & 7.261 & $1.643 * * *$ \\
\hline
\end{tabular}

(e.g., Oberlack et al. 2016, Dell'Angelo et al. 2017). See Appendix 1, A1.5 for the coding of each case.

Cross-site comparative analysis was conducted with qualitative comparative analysis (QCA). Qualitative comparative analysis is a case-oriented method that uses Boolean logic to establish conditions causally associated with an outcome (Rihoux and Ragin 2009). Qualitative comparative analysis was chosen for two reasons. First, qualitative comparative analysis has been used widely to support causal inference about regional and global change, and it has the flexibility to accommodate causal factors at multiple scales (Rudel 2008, Schneider and Wagemann 2010). Given the complexities and local contingencies of ELC impacts, we used fuzzy-set QCA to allow for partial membership of cases to more than one causal configuration. Second, QCA is a robust and still growing research area (Schneider and Wagemann 2010) supported by many open-source platforms, such as R packages and dedicated QCA software (Rihoux and Ragin 2009, Thiem and Du 2013; Thomann and Wittwer, unpublished manuscript). We used fsQCA software version 3.0, developed by Ragin and Davey (2016) for our analysis.

Fuzzy-set QCA explores causal relationships between explanatory factors, or focus conditions, and outcome conditions that vary by level or degree. Outcome conditions (i.e., dependent variables) of interest were the presence or absence of iLUC (Table 2), which was derived based on forest loss in ELC-containing communes. Based on sensitivity analysis (see Appendix 1, A1.5), a forest loss threshold of $7.5 \%$ was used, which produced sufficiently high values for QCA solution consistency (above 0.9) and coverage (above 0.6 ). Focus conditions were produced from our case study coding, extracted for specific ELCs from ODC data, or derived from remote sensing analysis (Table 3). Fuzzyset membership scores were assigned to all conditions (Table 3 ) with values from 0 to 1 defining the extent to which a given case belongs to a set (Schneider and Wagemann 2010). Truth tables, a central analytic device in QCA, were then constructed using fuzzy membership values to assemble focus and outcome conditions into causal configurations. Execution of QCA produced three types of solutions based on different assumptions: complex, parsimonious, and intermediation solutions. As suggested by Schneider and Wagemann (2010), we ultimately selected intermediate solutions for reporting and interpreting the findings in this study. To ensure robust final solutions, we adjusted fuzzy membership scores for focus conditions until the intermediate solutions reached high consistency (i.e., above 0.9 ; Schneider and Wagemann 2010, Thomas et al. 2014), and validated the correct membership of individual cases to each final solution.

\section{RESULTS}

\section{Attribution of indirect land-use changes (iLUC) to economic land concessions (ELCs)}

Average treatment effects on the treated (ATT) estimated through propensity score matching suggested that communes containing an ELC were more likely to experience forest loss (iLUC) than communes that were not adjacent to an ELC. Specifically, communes containing ELCs producing rubber were 29.3\% more likely to experience iLUC than matched control communes (Table 4 , top). Communes containing ELCs producing cassava, palm oil, teak, cashew, sugar, or unknown crops did not experience statistically greater iLUC than their matched controls. Communes containing ELCs that underwent rapid direct LUC (within three years of ELC establishment) were $25.9 \%$ more likely to experience iLUC than matched control communes (Table 4, middle). Communes adjacent to ELCs that underwent gradual or no direct LUC did not experience statistically greater iLUC than their matched controls. Finally, a density-dependent threshold effect was also observed. Communes in provinces with greater than $20 \%$ land area in ELCs were $64.3 \%$ more likely to experience iLUC than matched control communes. Communes in provinces with less land area in ELCs did not experience statistically greater iLUC than their matched controls (Table 4, bottom). Combined, propensity score matching results indicated that crop type, rate of land conversion, and the presence of sufficient density of other 
ELCs as explanations for ELC-driven iLUC. Each of these factors were investigated further with the cross-site comparison and survival analyses to infer the causal mechanisms producing these patterns.

\section{Timing of economic land concession (ELC) establishment and direct land-use changes (LUC)}

Analysis of survival odds ratios, or odds of failure or survival relative to the base hazard rate, demonstrated that cassava and natural rubber prices were the dominant drivers of ELCs establishment (Table 5). An interaction term combining commodity prices and market influence index was created to spatially disaggregate time series of producer prices accounting for market access limitations. The ELCs for cassava were about 33\% less likely to occur later in the study period, whereas the ELCs for rubber were about $44 \%$ more likely later in the study period. An ELC dummy variable also showed that there were significant fixed effects attributed to unobserved heterogeneity across ELCs that affected occurrence probability. Sugar, hard log, and palm oil prices were removed from the analysis because of their correlation with natural rubber prices to avoid variable inflation. Plotting the survival probabilities of ELCs by crop type showed distinct waves of commodity crop expansion (Fig. 4). Early ELCs were motivated by higher cassava and cashew prices because the majority of ELCs producing those crops occurred prior to the start of the study period (i.e., unobserved or censored events) and/or prior to 2007. After 2008, new ELCs were predominately rubber producing, and roughly 70\% of all rubber ELCs occurred between 2008 and 2012. Despite a dramatic price drop in rubber after February of 2011, deforestation within ELCs increased during this same period and beyond (Index Mundi 2018), yet Cambodian rubber exports were on the rise well into 2016 coinciding with the lag time between rubber planting and harvesting (Mahanty and Milne 2016).

Table 5. Survival analysis of time to economic land concessions (ELC) establishment. Interactions between market influence and commodity prices for natural rubber (pnrub) and cassava (pcass) were statistically significant. Statistically significant fixed effects for ELCs were also detected with a dummy variable for each deal (elcdmmy). Note: $\mathrm{SE}=$ standard error; $\mathrm{CI}=$ confidence interval; mktinf $=$ market information; $\mathrm{CROP}=$ crop type as defined in Table 4.

\begin{tabular}{lccccc}
\hline \hline Variable & Coeff & SE & $\mathrm{p}>|\mathrm{z}|$ & $\begin{array}{c}\text { Hazard } \\
\text { Ratio }\end{array}$ & 95\% CI \\
\hline pnrub*mktinf & 0.3624 & 0.1156 & 0.0017 & 1.4367 & $1.1455-1.8020$ \\
pcass*mktinf & -0.3954 & 0.1860 & 0.0335 & 0.6734 & $0.4677-0.9697$ \\
elcdmmy & 0.0034 & 0.0012 & 0.0057 & 1.0035 & $1.0010-1.0059$ \\
$\mathrm{~N}=210$ & & & & Stratified by \\
& & & & CROP \\
\hline
\end{tabular}

In contrast, commodity prices did not explain variation in the time between ELC establishment and the year of direct LUC (i.e., implementation). Declines in survival probabilities of forest cover within ELC boundaries (i.e., direct LUC) did not closely follow the timing of ELC establishment for all commodity crops (Fig. 5). Rubber ELCs were the exception with about $70 \%$ forest cover within ELC boundaries being cleared between 2010 and 2016 following high prices and rapid implementation. In contrast, roughly $80 \%$ of forest-cover loss within cassava ELCs did not occur until 2013 or later despite cassava being the primary commodity crop for early period ELCs. Also notable was that less than $40 \%$ of ELCs producing cashew, oil palm, or teak resulted in forest loss greater than the threshold forest loss (see Table 2).

Direct LUC was best predicted by the time elapsed since ELC establishment (Table 6). Forest loss within ELC boundaries was about $5 \%$ less likely since ELC establishment increased. Although small, time since ELC establishment had a significant protective effect on existing forest cover within ELCs, which suggested that ELC implementation and forest clearing became more difficult the more time passed since ELC establishment. Also, the abrupt increase in forest loss within ELCs after 2012 was likely related to the Cambodian government's Order 01 in May 2012, which issued a moratorium on new ELCs and required that active production begin or the concession would be revoked (Oldenburg and Neef 2014). The ELC dummy was again statistically significant indicating that unobserved heterogeneity among individual ELCs affected the probability of direct LUC.

Fig. 4. Survival analysis of time to economic land concessions (ELC) establishment. Interactions between market influence and commodity prices for natural rubber ('pnrub') and cassava ('pcass') were statistically significant. Statistically significant fixed effects for ELCs were also detected with a dummy variable for each deal ('elcdmmy').

Time to ELC Establishment

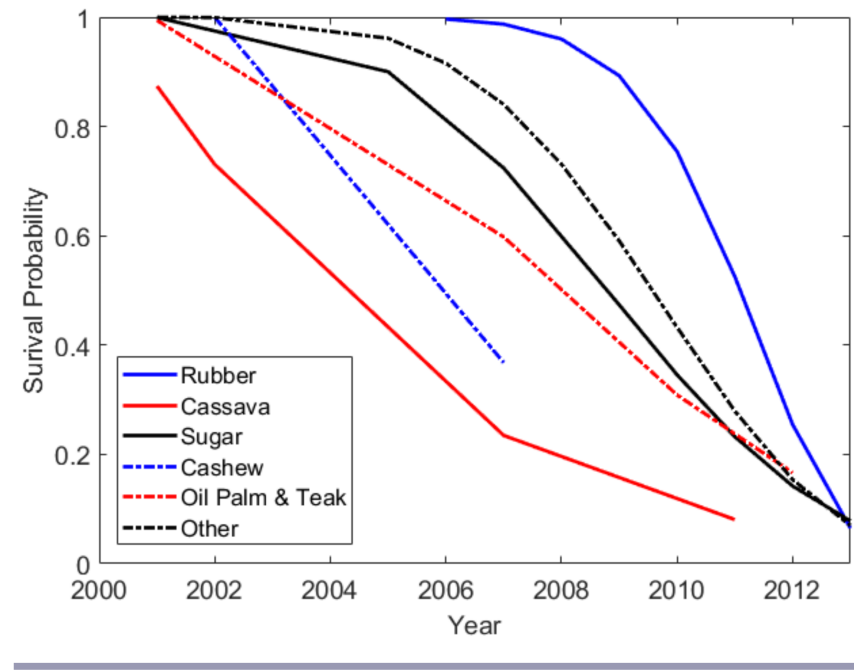

Causal socioeconomic configurations of indirect land-use change (iLUC)

The two most important metrics for QCA are consistency and coverage. The first refers to the degree to which the focus conditions lead to an outcome, whereas the other demonstrates how many cases with the outcomes are represented by a particular focus condition (Rihoux and Ragin 2009). Minimal acceptable levels in the literature for consistency and coverage of a complete solution are 0.9 and 0.5 , respectively (Legewie 2013). Complete solutions for both iLUC presence and absence were acceptable with respective consistency of 0.926 and 1 and coverage of 0.625 and 0.6. 
Table 6. Survival analysis of time to forest loss within economic land concessions (ELC) boundaries (i.e., ELC implementation and direct land-use change). Time since ELC establishment (t_since) and ELC fixed effects (elcdmmy were statistically significant. Note: $\mathrm{SE}=$ standard error; $\mathrm{CI}=$ confidence interval; $\mathrm{CROP}=$ crop type as defined in Table 4 .

\begin{tabular}{lccrcc}
\hline \hline Variable & Coeff & SE & $\mathrm{p}>|\mathrm{z}|$ & $\begin{array}{c}\text { Hazard } \\
\text { Ratio }\end{array}$ & $95 \%$ CI \\
\hline t_since & -0.0506 & 0.0232 & 0.0294 & 0.9507 & $0.9084-0.9950$ \\
elcdmmy & 0.0034 & 0.0014 & 0.0159 & 1.0034 & $1.0006-1.0061$ \\
$\mathrm{~N}=210$ & Log likelihood $=-678.4286$ & & Stratified by CROP \\
\hline
\end{tabular}

Fig. 5. Survival probability over the course of the study period of forest cover within economic land concessions (ELC) boundaries, disaggregated by commodity crop produced.

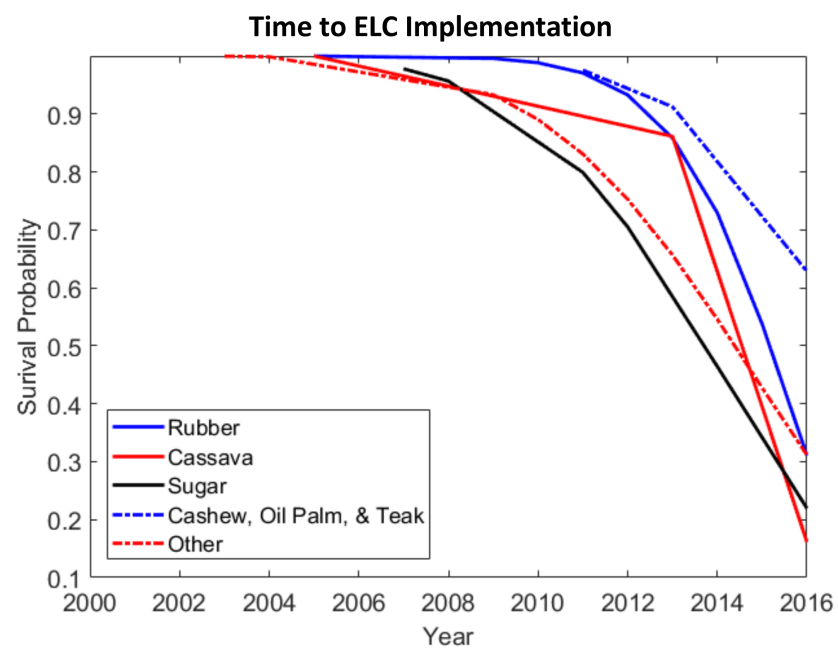

Six causal configurations were identified as leading to iLUC (Table 7). The first 4 configurations all involved rapid land conversion and were the most common causal configurations leading to iLUC ( 11 out of 13 cases covered). Although there were slight variations among the configurations, rapid direct LUC and displacement and/or conflict were common conditions, which was consistent with the typical conceptualization of ELCs as land grabs (e.g., et al. 2009, Zoomers 2010, Borras and Franco 2011, Edelman et al. 2013, Dell'Angelo et al. 2017). The remaining two configurations represented situations of gradual land conversion combined with iLUC as a means of resistance and conflict by local communities leading to a failed ELC (configuration 5), or ELC-induced displacement resulting in iLUC in prearranged resettlement areas.

Three causal configurations were associated with the absence of iLUC (Table 8). Configuration one had rapid land conversion to crops other than rubber combined with employment, conflict, no displacement, no compensation, and no immigration. Configuration two had gradual land conversion to rubber combined with conflict, no compensation, no employment, no immigration, and no displacement. These two configurations shared a lack of displacement and pressure from outside immigration, which commonly led to conflict and resistance against ELCs. The final configuration was not associated with iLUC, but shared many focus conditions of causal configurations found to be associated with iLUC, such as rapid land conversion, displacement, and conflict. After cross-checking the case study narratives, remote sensing forest loss statistics, and survival analysis results, we found that the cases associated with this configuration were qualitatively more similar to those leading to iLUC. Sensitivity analysis of the forest-loss threshold found that at threshold hold values below $5 \%$, these cases would be reassigned to configurations leading to iLUC.

It is also important to note that not all cases conformed sufficiently with or were covered by the causal configurations produced from the QCA, as indicated by the consistency measures and case coverage. This was because of the choice of forest-loss threshold value or the simplifications required to code complex variables for use in the QCA. In particular, reported conflicts took many forms and were not always causally linked to direct or indirect LUC by the case study authors. Additionally, there were many other ELCs that were established or established and implemented without being reported in the case study literature, which was biased toward conflictual contexts. For these reasons, some causal configurations were combined into a single archetypical pathway, or additional archetypical pathways were introduced based on ELC characteristics and remote sensing data alone to cover situations not reported in the case study literature. Thus, there was not a one-to-one correspondence between the causal configurations produced by the QCA and the causal pathways. These findings suggest a limitation of using QCA in isolation and the added explanatory power obtained with mixed methods triangulation.

\section{Archetypical pathways of economic land concessions' (ELC) socioeconomic and land-use change}

Three main findings from the propensity score matching and survival analyses structured the QCA coding and enabled the construction of causal pathways linking ELCs to iLUC in Cambodia: (1) ELCs producing rubber were more likely to lead to iLUC than other commodity crops; (2) the faster the rate of direct LUC within ELC boundaries the more likely iLUC in adjacent communes followed; and (3) there was a positive relationship between increasing density of ELCs at the provincial level and iLUC. Based on these insights, 12 distinct archetypical pathways, 5 leading to iLUC (Fig. 6) and 7 leading to negligible iLUC (Fig. 7), to describe 210 ELCs emerged from our findings. Each pathway links the type of commodity crop associated with an ELC, the rate of direct LUC observed via remote sensing, and causal configurations of socioeconomic consequences that led to (or not) iLUC. Archetypical pathways that produced iLUC included land grabs with and without physical displacement of local communities, arranged resettlement of displaced communities, and failed ELCs. Land-grab pathways often involved political-economic means of dispossession of communal land, exploitation of informal or incomplete land titling of marginalized communities, and/or a lack of transparency in the concession-granting process. In these cases, iLUC often resulted immediately adjacent to ELC boundaries in an effort by smallholders to halt further expansion of large-scale agriculture by establishing land-ownership claims to resist displacement, or 
Table 7. Intermediate qualitative comparative analysis (QCA) solution for the emergence of indirect land-use change (iLUC). Note: ELC $=$ economic land concessions.

\begin{tabular}{|c|c|c|c|c|c|c|}
\hline Causal configurations & $\begin{array}{c}\text { (1) LC_RATE * } \\
\text { TREE* } \sim \text { EMP } * * \\
\text { DISP* } \\
\sim \text { IMM * CONF }\end{array}$ & $\begin{array}{c}\text { (2) } \mathrm{LC}_{-} \mathrm{RATE}^{*} \\
\mathrm{TREE} * \text { COMP } \\
* \sim \mathrm{EMP}^{*} \mathrm{DISP} * \\
\text { CONF }\end{array}$ & $\begin{array}{c}\text { (3) LC_RATE* } \\
\text { TREE*COMP* } \\
\text { EMP*DISP* }^{*} \text { DISP } \\
\text { IMM*CONF }\end{array}$ & $\begin{array}{l}\text { (4) LC_RATE } * \\
\text { TREE } * \text { COMP } * \\
\text { EMP * DISP } * \\
\text { IMM * CONF }\end{array}$ & $\begin{array}{l}\text { (5) } \sim \text { LC_RATE } * \\
\text { TREE } * \sim \text { COMP } \\
* \sim \text { EMP } * \sim \text { DISP } \\
* \sim \text { IMM } * \sim \text { CONF }\end{array}$ & $\begin{array}{l}\text { (6) } \sim \text { LC_RATE } * \sim \\
\text { TREE } * \text { COMP } * \sim \\
\text { EMP } * \text { DISP } * \\
\sim \text { IMM } * \sim \text { CONF }\end{array}$ \\
\hline & 0.846 & 1 & 1 & 1 & 1 & 1 \\
\hline Raw c & 75 & 0.15 & 0.05 & 0.0 & 0.05 & 0.05 \\
\hline $\begin{array}{l}\text { Case coverage (Case } \\
\text { ID) }\end{array}$ & $\begin{array}{l}36,111,278 \\
154,253,24\end{array}$ & $188,87,88$ & 204 & 259 & 169 & 15 \\
\hline Solution formula & \multicolumn{6}{|c|}{$\begin{array}{l}\text { LC_RATE* CONF*(TREE* EMP* DISP* IMM + COMP*DISP }(\text { TREE* EMP*DISP + } \sim \text { TREE*EMP*IMM }))+\sim \\
\text { LC_RATE* IMM* }{ }^{*} \sim \text { CONF* }^{*} \sim \text { EMP }^{*}\left(\text { TREE }^{*} \sim \text { COMP }^{*} \sim \text { DISP }+\sim \text { TREE*COMP*DISP }\right) \rightarrow \text { iLUC }\end{array}$} \\
\hline Solution & 0.926 & & & & & \\
\hline Solution coverage & 0.625 & & & & & \\
\hline
\end{tabular}

Variables: Land conversion rate (LC_RATE), rubber crop (TREE), compensation from ELC (COMP), employment with ELC (EMP), displacement of local inhabitants (DISP), immigration to ELC-impacted areas (IMM), and direct and/or indirect conflict (CONF).

Note: $*=$ and,$\sim=$ absence of, $+=$ or; $\rightarrow=$ sufficient for. Case ID refers to the unique identifier linking specific ELCs reported in case studies to their corresponding georeferenced boundaries (see Appendix 1, Table A1.4.2).

by the establishment of farms by inmigrants employed by the concessionaires (Fox et al. 2018). The resettlement pathway was characterized by forced or negotiated resettlement of communities dispossessed and displaced by an ELC, often to less productive land, which resulted in forest clearing and establishment of new cultivated plots in the nearby resettled areas. Finally, in a small number of cases (e.g., Gironde and Peeters 2015), smallholders alerted to the granting of an ELC preemptively cleared and occupied land within the planned ELC boundaries and prevented it from going into production.

Fig. 6. Archetypical pathways of economic land concessions (ELCs) leading to indirect land-use change (iLUC).

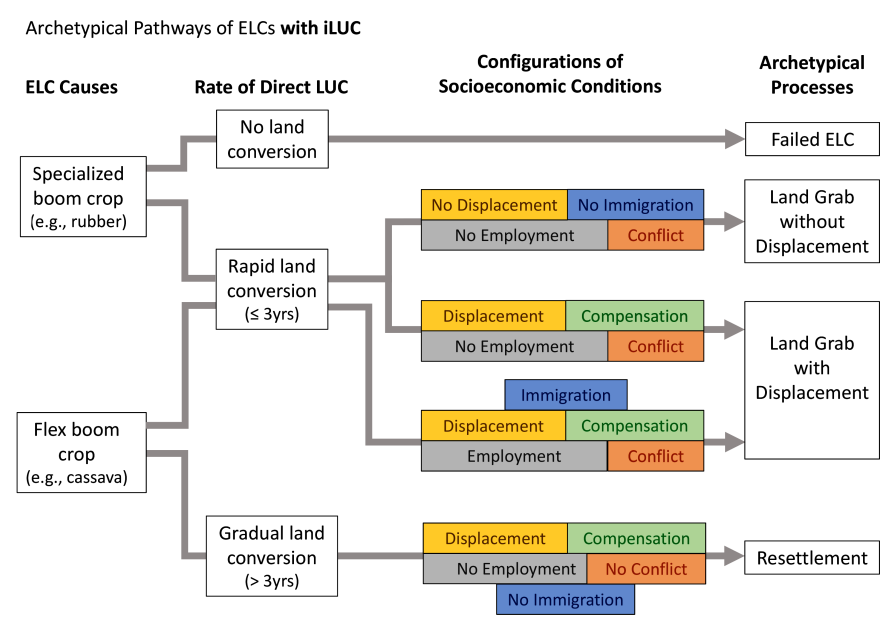

Of the seven archetypical pathways that did not lead to iLUC (Fig. 7), two were consistent with narratives of successful local resistance against displacement by ELCs (e.g., Neef et al. 2013). In some cases, declines in commodity prices combined with direct conflict with local communities to discourage investors from moving forward with production (e.g., Baird 2017). In other cases, ELCs associated with flex crops offered direct employment and/or compensation for lost access to land, which lessened pressures for iLUC. For palm oil and sugar, in particular, supply-chain governance played a role in avoiding some of the negative socioeconomic consequences that were associated with iLUC (e.g., Beban et al. 2017). The remaining archetypical pathways that did not lead to iLUC involved: (1) large-scale production ELCs, which entailed progression of ELCs from establishment to full-scale implementation ( $>10 \%$ direct LUC) without observed social impacts; (2) small-scale production in which direct LUC was observed but at a spatial extent below the threshold level of $10 \%$; or (3) speculative or revoked ELC which resulted in gradual direct LUC at an extent less than $10 \%$ of the granted area or no LUC at all.

Fig. 7. Archetypical pathways of economic land concessions (ELCs) that did not result in indirect land-use change (iLUC).

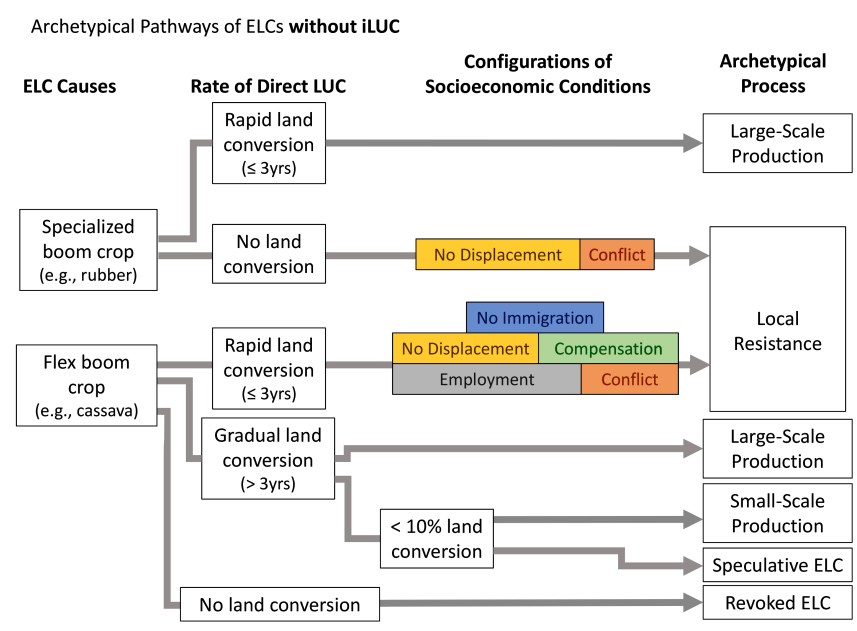


Table 8. Intermediate qualitative comparative analysis (QCA) solution for the absence of indirect land-use change (iLUC). Note: ELC $=$ economic land concessions.

\begin{tabular}{|c|c|c|c|}
\hline Causal configurations & $\begin{array}{l}\text { (1) LC_RATE } * \sim \text { TREE } * \text { COMP } * \\
\text { EMP } * \sim \text { DISP } * \sim \text { IMM * CONF }\end{array}$ & $\begin{array}{l}(2) \sim \text { LC_RATE } * \text { TREE * } * \text { COMP * } \sim \text { EMP } \\
* \sim \text { DISP * IMM * CONF }\end{array}$ & $\begin{array}{l}\text { (3) } \mathrm{LC} \_ \text {RATE } * \sim \text { TREE * COMP } \\
\text { * EMP* DISP * } \sim \mathrm{IMM} * \text { CONF }\end{array}$ \\
\hline Consistency & 1 & 1 & 1 \\
\hline Raw coverage & 0.2 & 0.1 & 0.3 \\
\hline Case coverage (Case ID) & 151,152 & 110 & $18,156,22$ \\
\hline Solution formula & \multicolumn{3}{|c|}{$\begin{array}{l}\sim \text { IMM*CONF* }\left(\sim \text { LC_RATE*TREE* }{ }^{*} \text { COMP* EMP* DISP + LC_RATE* TREE* EMP*(COMP* DISP + COMP* }\right. \\
\text { DISP })) \rightarrow \text { no iLUC }\end{array}$} \\
\hline Solution consistency & 1 & & \\
\hline Solution coverage & 0.6 & & \\
\hline
\end{tabular}

\section{DISCUSSION}

We synthesized the processes and outcomes of LUC across multiple ELCs to assess whether they led to iLUC based on their characteristics, land-acquisition processes, associated rates and types of LUCs, and the social-environmental contexts in which they are embedded. Our findings support the current understanding in the literature related to positive and negative effects of ELCs on rural economies. Consistent with narratives of land grabbing in the literature, we found that many ELCs intended for specialized commodity crops, such as rubber, were established through informal or otherwise opaque means, and rapid implementation following establishment often resulted in displacement of and/or conflict with local communities. Similarly, we found alternative pathways for iLUC in which smallholders became agents of land grabbing by establishing cultivated plots at the fringe of ELCs for which they worked (Lamb et al. 2017, Fox et al. 2018), and/or land was cleared within the same commune in anticipation of future ELCs leading to compensation, land titling, or employment (Neef et al. 2013, Gironde and Peeters 2015). Conversely, we found that there was no single pathway that led to successful local resistance to ELC establishment or implementation. Qualitative evidence from individual case studies points to the presence of social organization, a community leader, and/or sufficient notification of ELC establishment as factors explaining successful resistance (e.g., Gironde and Peeters 2015, Baird 2017). Our findings supplement these explanations by demonstrating the rate and extent of direct LUC from ELC implementation as important causal considerations.

This synthesis research approach also made two new contributions to the understanding of ELCs in Cambodia and the LSLA phenomenon more broadly. First, this is the first analysis to systematically connect initiating causes of ELCs in Cambodia (i.e., commodity price dynamics, investor and crop characteristics) to cascading processes of direct and indirect LUC and socioeconomic impacts across space and time. Each of these factors or processes have been previously studied individually or in limited combinations, e.g., commodity prices and boom crop expansion (Hurni et al. 2017), but not social impacts; land grabs and land dispossession (Dell'Angelo et al. 2017) but not LUC, but their linkage into coherent pathways is novel and helps to navigate the complexity presented across the case study literature.
For example, cassava is typically identified as a boom crop in the literature (e.g., Mahanty and Milne 2016), and indeed we found an archetypical pathway involving cassava, rapid direct LUC, displacement, and extensive iLUC resembling that of land grabs for rubber production. However, we found that cassava's multipleuse characteristics, relative insensitivity to commodity prices and stable market demand, particularly compared to rubber, could also manifest in pathways of no iLUC under conditions of gradual direct LUC and minimal conflict.

Second, our synthesis across all ELCs in Cambodia highlighted a bias in the literature. Examples of ELCs that progressed to largescale production without conflict are under-reported, while much attention is given to conflictual contexts associated with land grabs. We constructed two archetypical pathways (covering 23 ELCs), independent of commodity crop type and rate of direct LUC, leading to large-scale production ELCs in which substantial direct LUC occurred without any reported social impacts or observed iLUC. The pathway associated with multiple-use crops suggested that a gradual transition from establishment to implementation can avoid or mitigate social impacts that could otherwise lead to iLUC. Alternatively, the pathway associated with specialized crops suggested that ELCs can be located in such a way that little community displacement results, and/or social impacts can be sufficiently minimized or managed to avoid drawing the attention of media and researchers. These findings illustrate that various configurations with the same initiating cause (e.g., spike in rubber prices) can manifest different outcomes (e.g., displacement versus employment of local community members) and different causes manifest the same outcome (e.g., displacement and iLUC) given local conditions.

Pathways leading to iLUC are of significant concern for halting or mediating LUC brought about by ELCs in Cambodia and LSLAs more generally. For example, policy interventions seeking to regulate or halt LUC associated with LSLAs may be ineffective because of iLUC resulting from the displacement of previous land users and/or transformative effects on the rural economy (e.g., Fox et al. 2018). Moreover, previous land uses are often displaced from suitable to marginal land for agriculture, which can accelerate land degradation (Lawrence et al. 2007, Runyan et al. 2012, Özdoğan et al. 2018) and/or exacerbate food insecurity and poverty of displaced land users (Golay and Biglino 2013). 
Producing insights that are actionable for policy development requires knowledge at a moderate level of generalization: capturing the nuances of locally varying conditions but sufficiently generalized to address common situations observed over a large region (Messerli et al. 2014, Carter et al. 2017). Archetypical pathways provide exactly this level of knowledge. Individual LSLAs can be described by a combination of contextual factors and causal processes linked together through space and time into a causal pathway, and common, repeating pathways observed across a production region constitute an archetypical pathway.

These archetypical pathways provide the departure point for developing middle-range theory about the causes and consequences of LUC associated with LSLAs. More broadly, this work contributes to nascent efforts to develop middle-range theories about land-use spillovers and displacements, specifically related to "activity leakage" (Meyfroidt et al. 2018). Activity leakage "occurs when production factors or inputs are highly mobile such that labor and capital used on the land targeted by the restrictions are reallocated to places with available and accessible land" (Meyfroidt et al. 2018:60). Linking back to our conceptual framework of commodity crop production pathways, we found five archetypical pathways that led to iLUC associated with the establishment and implementation of ELCs. These pathways were largely consistent with land-use cascade and displacement effects theorized in the land-system science literature (e.g., Lambin and Meyfroidt 2011) and described in existing narratives around land grabs. This suggests an opportunity to test the generality of these pathways beyond the Cambodian context and with other commodity crops demonstrating short lags between establishment and implementation. Thus, the archetypical pathways we constructed provide generalized yet contextually bounded pathways that can be empirically investigated in other LSLA-receiving regions in Southeast Asia and similar world regions.

\section{Limitations}

Our mixed methods triangulation approach to archetype analysis required a wide range of data types, and thus data quality and completeness were concerns across all of the analyses. Data demands, particularly for survival analysis, were high because time series were central to understanding causal effects. For landuse categories and socioeconomic measures, only cross-sectional data for a single year was available, whereas repeated crosssectional observations or panel data would have likely improved inference. As with any use of satellite-derived land-use classification datasets, there was inherent uncertainty in detection and classification accuracy (Rindfuss et al. 2004, Messerli et al. 2014, Khuc et al. 2018), but use of the well-vetted GFC data product (Hansen et al. 2013) bounded these concerns. Other potentially important data, such as migration flows between communes or subnational governance indicators, which could be strong predictors of ELC establishment and iLUC, were not available. Although we conducted sensitivity analyses (i.e., Rosenbaum bounds for matching) and robustness checks (i.e., leading variables for survival analysis), the omission of potentially explanatory variables because of data limitations remains an area for improvement.

In addition, many of the inferential bridges made between analyses relied on defining thresholds or overlapping categories based on expert judgement. For instance, threshold values were used to calibrate the fuzzy membership scores for focus conditions in QCA, and rates or indicators of direct and indirect LUC relied on forest loss thresholds based on visual inspection of remote sensing imagery for known ELCs in Cambodia. Although such judgements were unavoidable when filling data or knowledge gaps between datasets and analyses, they may have generated undetected bias or may not be as meaningful in other contexts. This will need to be tested in future work.

Finally, although the collection of case studies was geographically representative, they were not comprehensive with respect to the diversity of possible pathways of direct and indirect LUC. Extrapolation of our archetypical pathways to ELCs not directly reported on by case studies using attributes observed across all ELCs, e.g., crop type, rate of ELC direct LUC, and presence/ absence of iLUC, covered all eligible ELCs. Consistency of classification of individual cases was checked for each pathway and partial membership and contradictory outcomes were present. Thus, archetypical pathways should be considered broadly applicable generalizations of causal chains rather than crisp predictors of any case.

\section{CONCLUSIONS}

Despite these limitations, this study advances current synthesis research in land-system science beyond individual frequency, or configuration-based methods (Magliocca et al. 2015, van Vliet et al. 2016) by integrating multiple methods to explicitly consider the sequence of events. Such integration enabled investigation and quantification of pathways leading to iLUC, which has only been done successfully in a few land-change contexts (Arima et al. 2011, Deininger and Xia 2016). This was possible through mixed method triangulation that used process-based insights from case studies to draw meaningful categorical distinctions to inform the quantitative analyses. In addition, these methods are an early example of following best practices for producing generalized knowledge claims (Magliocca et al. 2018). This included an explicit description of the logic of generalization used to align various scales of observations, levels of inference, and conditionality of archetypical pathways.

Our study also conceptually advances the frontiers of synthesis in land-system science by combining concepts of causal pathways (Lambin and Meyfroidt 2011, Meyfroidt et al. 2013, 2014) and archetypes (Oberlack et al. 2016) to simultaneously investigate commodity-driven agricultural expansion and land-system change. The archetypes approach identified generalizable building blocks of repeated associations among specific of commodity crops, local land-acquisition processes, and timing of direct and indirect LUC. Operationalizing the concept of causal pathways guided inference about causal mechanisms linking archetypical building blocks, which is a much-needed progression beyond pattern-based models of land-use change (Meyfroidt 2016). The archetypical pathways approach also integrated various conceptualizations of boom crops (Mahanty and Milne 2016, Hurni et al. 2017, Fox et al. 2018), commodity-driven agricultural expansion (Meyfroidt et al. 2013, 2014, Ordway et al. 2017), livelihood impacts of LSLAs (Oberlack et al. 2016), and spillover effects (Arima et al. 2011, Deininger and Xia 2016). Consequently, archetypical pathways of LSLA-driven change posited here for the Cambodian context were analyzed at a level of generality that lends itself to testing across the broader 
Southeast Asian region and other contexts experiencing LSLAs. With broad theoretical grounding and synthesis at the level of causal mechanisms, this study contributes to the development of middle-range theories of commodity-driven livelihood and landuse change.

Responses to this article can be read online at: http://www.ecologyandsociety.org/issues/responses. php/10954

\section{Acknowledgments:}

The authors acknowledge support from NASA ROSES Land Cover Land Use Change project LCLUC project Award \#NNX17AI15G. This study contributes to the Global Land Programme (https://glp. earth).

\section{LITERATURE CITED}

An, L., and D. G. Brown. 2008. Survival analysis in land change science: integrating with GIScience to address temporal complexities. Annals of the Association of American Geographers 98(2):323-344. https://doi.org/10.1080/00045600701879045

Anseeuw, W., J. Lay, P. Messerli, M. Giger, and M. Taylor. 2013. Creating a public tool to assess and promote transparency in global land deals: the experience of the Land Matrix. Journal of Peasant Studies 40(3):521-530. https://doi.org/10.1080/0306615$\underline{0.2013 .803071}$

Arima, E. Y., P. Richards, R. Walker, and M. M. Caldas. 2011. Statistical confirmation of indirect land use change in the Brazilian Amazon. Environmental Research Letters 6(2):024010. https://doi.org/10.1088/1748-9326/6/2/024010

Baird, I. G. 2010. Land, rubber and people: rapid agrarian changes and responses in Southern Laos. Journal of Lao Studies 1(1):1-47. [online] URL: http://www.laostudies.org/system/files/ subscription/JLS-v1-i1-Jan2010-baird.pdf

Baird, I. G. 2011. Turning land into capital, turning people into labor: primitive accumulation and the arrival of large-scale economic land concessions in the Lao People's Democratic Republic. New Proposals: Journal of Marxism and Interdisciplinary Inquiry 5(1):10-26.

Baird, I. G. 2014. The global land grab meta-narrative, Asian money laundering and elite capture: reconsidering the Cambodian context. Geopolitics 19(2):431-453. https://doi. org/10.1080/14650045.2013.811645

Baird, I. G. 2017. Resistance and contingent contestations to large-scale land concessions in Southern Laos and Northeastern Cambodia. Land 6(1):16. https://doi.org/10.3390/land6010016

Baird, I. G., and J. Fox. 2015. How land concessions affect places elsewhere: telecoupling, political ecology, and large-scale plantations in Southern Laos and Northeastern Cambodia. Land 4(2):436-453. https://doi.org/10.3390/land4020436

Balehegn, M. 2015. Unintended consequences: the ecological repercussions of land grabbing in Sub-Saharan Africa.
Environment: Science and Policy for Sustainable Development 57 (2):4-21. https://doi.org/10.1080/00139157.2015.1001687

Barney, K. 2009. Laos and the making of a "relational" resource frontier. Geographical Journal 175(2):146-159. https://doi. org/10.1111/j.1475-4959.2009.00323.X

Beauchamp, E., T. Clements, and E. J. Milner-Gulland. 2018. Exploring trade-offs between development and conservation outcomes in Northern Cambodia. Land Use Policy 71:431-444. https://doi.org/10.1016/j.landusepol.2017.11.021

Beban, A., S. So, and K. Un. 2017. From force to legitimation: rethinking land grabs in Cambodia. Development and Change 48 (3):590-612. https://doi.org/10.1111/dech.12301

Bennett, E. M., G. S. Cumming, and G. D. Peterson. 2005. A systems model approach to determining resilience surrogates for case studies. Ecosystems 8(8):945-957. https://doi.org/10.1007/ s10021-005-0141-3

Blackman, A., A. Pfaff, and J. Robalino. 2015. Paper park performance: Mexico's natural protected areas in the 1990s. Global Environmental Change 31:50-61. https://doi.org/10.1016/j. gloenvcha.2014.12.004

Borras, S. M., Jr., and J. C. Franco. 2011. Political dynamics of land-grabbing in Southeast Asia: understanding Europe's role. Transnational Institute, Amsterdam, The Netherlands. [online] URL: https://www.tni.org/files/download/Political $\% 20$ Dynamics $\%$ 20of $\% 20$ Land-grabbing $\% 20$ in $\% 20$ Southeast $\% 20$ Asia.pdf

Borras, S .M., Jr., J. C. Franco, S. R. Isakson, L. Levidow, and P. Vervest. 2016. The rise of flex crops and commodities: implications for research. Journal of Peasant Studies 43(1): 93-115. https://doi.org/10.1080/03066150.2015.1036417

Breu, T., C. Bader, P. Messerli, A. Heinimann, S. Rist, and S. Eckert. 2016. Large-scale land acquisition and its effects on the water balance in investor and host countries. PLOS ONE 11(3): e0150901. https://doi.org/10.1371/journal.pone.0150901

Caliendo, M., and S. Kopeinig. 2008. Some practical guidance for the implementation of propensity score matching. Journal of Economic Surveys 22(1):31-72. https://doi.org/10.1111/ j.1467-6419.2007.00527.X

Carter, S., A. M. Manceur, R. Seppelt, K. Hermans-Neumann, M. Herold, and L. Verchot. 2017. Large scale land acquisitions and REDD+: a synthesis of conflicts and opportunities. Environmental Research Letters 12(3):035010. https://doi. org/10.1088/1748-9326/aa6056

Cotula, L., S. Vermeulen, R. Leonard, and J. Keeley. 2009. Land grab or development opportunity? Agricultural investment and international land deals in Africa. IIED/FAO/IFAD, London, England/Rome, Italy. [online] URL: http://www.fao.org/3/aak241e.pdf

Cotula, L. 2012. The international political economy of the global land rush: a critical appraisal of trends, scale, geography and drivers. Journal of Peasant Studies 39(3-4):649-680. https://doi. org/10.1080/03066150.2012.674940

Davis, K. F., K. Yu, M. C. Rulli, L. Pichdara, and P. D’Odorico. 2015. Accelerated deforestation driven by large-scale land 
acquisitions in Cambodia. Nature Geoscience 8(10):772-775. https://doi.org/10.1038/ngeo2540

DeFries, R. S., T. Rudel, M. Uriarte, and M. Hansen. 2010. Deforestation driven by urban population growth and agricultural trade in the twenty-first century. Nature Geoscience 3(3):178-181. https://doi.org/10.1038/ngeo756

Deininger, K., and F. Xia. 2016. Quantifying spillover effects from large land-based investment: the case of Mozambique. World Development 87:227-241. https://doi.org/10.1016/j.worlddev.2016.06.016

Dell'Angelo, J., P. D’Odorico, M. C. Rulli, and P. Marchand. 2017. The tragedy of the grabbed commons: coercion and dispossession in the global land rush. World Development 92:1-12. https://doi. org/10.1016/j.worlddev.2016.11.005

Dell'Angelo, J., M. C. Rulli, and P. D'Odorico. 2018. The global water grabbing syndrome. Ecological Economics 143:276-285. https://doi.org/10.1016/j.ecolecon.2017.06.033

DiPrete, T. A., and M. Gangl. 2004. Assessing bias in the estimation of causal effects: Rosenbaum bounds on matching estimators and instrumental variables estimation with imperfect instruments. Sociological Methodology 34(1):271-310. https://doi. org/10.1111/j.0081-1750.2004.00154.X

D'Odorico, P., and M. C. Rulli. 2014. The land and its people. Nature Geoscience 7(5):324-325. https://doi.org/10.1038/ngeo2153

Dwyer, M. B. 2015. The formalization fix? Land titling, land concessions and the politics of spatial transparency in Cambodia. Journal of Peasant Studies 42(5):903-928. https://doi. org/10.1080/03066150.2014.994510

Eckert, S., M. Giger, and P. Messerli. 2016. Contextualizing localscale point sample data using global-scale spatial datasets: lessons learnt from the analysis of large-scale land acquisitions. Applied Geography 68:84-94. https://doi.org/10.1016/j.apgeog.2016.01.008

Edelman, M. 2013. Messy hectares: questions about the epistemology of land grabbing data. Journal of Peasant Studies 40(3):485-501. https://doi.org/10.1080/03066150.2013.801340

Edelman, M., C. Oya, and S. M. Borras, Jr. 2013. Global land grabs: historical processes, theoretical and methodological implications and current trajectories. Third World Quarterly 34 (9):1517-1531. https://doi.org/10.1080/01436597.2013.850190

Eisenack, K., S. Villamayor-Tomas, G. Epstein, C. Kimmich, N. R. Magliocca, D. Manuel-Navarrete, C. Oberlack, M. Roggero, and D. Sietz. 2019. Design and quality criteria for archetype analysis. Ecology and Society. XX(YY):ZZ.

Fairbairn, M. 2014. 'Like gold with yield': evolving intersections between farmland and finance. Journal of Peasant Studies 41 (5):777-795. https://doi.org/10.1080/03066150.2013.873977

Fox, J., T. Nghiem, H. Kimkong, K. Hurni, and I. G. Baird. 2018. Large-scale land concessions, migration, and land use: the paradox of industrial estates in the Red River delta of Vietnam and rubber plantations of Northeast Cambodia. Land 7(2):77. https://doi.org/10.3390/land7020077

Gironde, C., C. Golay, and P. Messerli. 2016. Large-scale land acquisitions: focus on South-East Asia. Brill Nijhoff, Leiden, The Netherlands. https://doi.org/10.1163/9789004304758
Gironde, C., and A. Peeters. 2015. Land acquisitions in Northeastern Cambodia: space and time matters. Pages 5-6 in LDPI conference in Chiang Mai University. BRICS Initiatives for Critical Agrarian Studies (BICAS)/MOSAIC Research Project/ Land Deal Politics Initiative (LDPI)/RCSD Chiang Mai University/Transnational Institute, Amsterdam, The Netherlands/ Oakland, California/The Hague, The Netherlands/Chiang Mai, Thailand/Amsterdam, The Netherlands. [online] URL: https:// www.iss.n1/sites/corporate/files/CMCP 24- Gironde Peeters.pdf

Gironde, C., and G. S. Portilla. 2015. From lagging behind to losing ground: Cambodian and Laotian household economy and large-scale land acquisitions. Pages 173-204 in C. Gironde, C. Golay, and P. Messerli, editors. Large-scale land acquisitions. International Development Policy/Revue internationale de politique de développement 6. Brill, Amsterdam, The Netherlands. https://doi.org/10.1163/9789004304758 008

Golay, C., and I. Biglino. 2013. Human rights responses to land grabbing: a right to food perspective. Third World Quarterly 34:1630-1650. https://doi.org/10.1080/01436597.2013.843853

Hansen, M. C., P. V Potapov, R. Moore, M. Hancher, S. A. Turubanova, A. Tyukavina, D. Thau, S. V. Stehman, S. J. Goetz, T. R. Loveland, A. Kommareddy, A. Egorov, L. Chini, C. O. Justice, and J. R. G. Townshend. 2013. High-resolution global maps of 21 st-century forest cover change. Science 342 (6160):850-853.

Hurni, K., A. Schneider, A. Heinimann, D. H. Nong, and J. Fox. 2017. Mapping the expansion of boom crops in mainland Southeast Asia using dense time stacks of landsat data. Remote Sensing 9(4):320. https://doi.org/10.3390/rs9040320

Index Mundi. 2018. Global commodity prices: rubber. Index Mundi. [online] URL: http://www.indexmundi.com/commodities/? commodity $=$ rubber \&months $=180$

International Land Coalition (ILC), Centre de Coopération Internationale en Recherche Agronomique pour le Développement (DDIRAD), Centre for Development and Environment (CDE), German Institute of Global and Area Studies (GIGA), and Deutsche Gesellschaft für Internationale Zusammenarbeit (GIZ). 2018. The land matrix global observatory. Land Matrix, Centre for the Study of Governance Innovation, Pretoria, South Africa. https://landmatrix.org/global/

Jung, S., C. Liao, A. Agrawal, and D. G. Brown. 2019. Evidence on wealth-improving effects of forest concessions in Liberia. Journal of the Association of Environmental and Resource Economists.[online] URL: https://suhyunjung.com/wp-content/ uploads/2018/11/JAERE R2 102918.pdf

Keele, L. 2010. An overview of rbounds: an $R$ package for Rosenbaum bounds sensitivity analysis with matched data. White Paper, Columbus, Ohio, USA. [online] URL: http://citeseerx.ist. psu.edu/viewdoc/download:jsessionid $=6372 \mathrm{D} 853 \mathrm{~A} 62 \mathrm{FBBF} 3 \mathrm{BD}-$ 10E8CB5F6FD5CC?doi=10.1.1.408.7360\&rep=rep1\&type $=$ pdf

Keene, S., M. Walsh-Dilley, W. Wolford, W. and C. Geisler. 2015. A view from the top: examining elites in large-scale land deals. Canadian Journal of Development Studies/Revue canadienne d'études du développement 36(2):131-146. https://doi. org/10.1080/02255189.2015.1044503 
Khuc, Q. V., B. Q. Tran, P. Meyfroidt, and M. W. Paschke. 2018. Drivers of deforestation and forest degradation in Vietnam: an exploratory analysis at the national level. Forest Policy and Economics 90(February):128-141. https://doi.org/10.1016/j. forpol.2018.02.004

Lamb, V., L. Schoenberger, C. Middleton, and B. Un. 2017. Gendered eviction, protest and recovery: a feminist political ecology engagement with land grabbing in rural Cambodia. Journal of Peasant Studies 44(6):1215-1234. https://doi. org/10.1080/03066150.2017.1311868

Lambin, E. F., and P. Meyfroidt. 2011. Global land use change, economic globalization, and the looming land scarcity. Proceedings of the National Academy of Sciences 108 (9):3465-3472. https://doi.org/10.1073/pnas.1100480108

Lawrence, D., P. D’Odorico, L. Diekmann, M. Delonge, R. Das, and J. Eaton. 2007. Ecological feedbacks following deforestation create the potential for a catastrophic ecosystem shift in tropical dry forest. Proceedings of the National Academy of Sciences 104 (52):20696-20701. https://doi.org/10.1073/pnas.0705005104

Legewie, N. 2013. An introduction to applied data analysis with qualitative comparative analysis. Forum Qualitative Sozialforschung/ Forum: Qualitative Social Research 14(3). http://dx.doi. org/10.17169/fqs-14.3.1961

Levers, C., D. Müller, K. Erb, H. Haberl, M. R. Jepsen, M. J. Metzger, P. Meyfroidt, T. Plieninger, C. Plutzar, J. Stürck, P. H. Verburg, P. J. Verkerk, and T. Kuemmerle. 2018. Archetypical patterns and trajectories of land systems in Europe. Regional Environmental Change 18(3):715-732. https://doi.org/10.1007/ $\underline{\mathrm{s} 10113-015-0907-\mathrm{X}}$

Magliocca, N. R., E. C. Ellis, G. R. H. Allington, A. de Bremond, J. Dell'Angelo, O. Mertz, P. Messerli, P. Meyfroidt, R. Seppelt, and P. H. Verburg. 2018. Closing global knowledge gaps: producing generalized knowledge from case studies of socialecological systems. Global Environmental Change 50:1-14. https:// doi.org/10.1016/j.gloenvcha.2018.03.003

Magliocca, N. R., T. K. Rudel, P. H. Verburg, W. J. McConnell, O. Mertz, K. Gerstner, A. Heinimann, and E. C. Ellis. 2015. Synthesis in land change science: methodological patterns, challenges, and guidelines. Regional Environmental Change 15 (2):211-226.. https://doi.org/10.1007/s10113-014-0626-8

Mahanty, S., and S. Milne. 2016. Anatomy of a boom: cassava as a 'gateway' crop in Cambodia's north eastern borderland. Asia Pacific Viewpoint 57(2):180-193. https://doi.org/10.1111/apv.12122

McKenney, B., Y. Chea, P. Tola, and T. Evans. 2004. Focusing on Cambodia's high value forests: livelihood and management. Cambodia Development Resource Institute. Wildlife Conservation Society, Phnom Penh, Cambodia. [online] URL: https://www. cdri.org.kh/publication-page-old/pub/sr/HVF3.pdf

Mertens, D. M., and S. Hesse-Biber. 2012. Triangulation and mixed methods research. Journal of Mixed Methods Research 6 (2):75-79. https://doi.org/10.1177/1558689812437100

Messerli, P., M. Giger, M. B. Dwyer, T. Breu, and S. Eckert. 2014. The geography of large-scale land acquisitions: analysing socio- ecological patterns of target contexts in the global South. Applied Geography 53:449-459. https://doi.org/10.1016/j.apgeog.2014.07.005

Meyfroidt, P. 2016. Approaches and terminology for causal analysis in land systems science. Journal of Land Use Science 11 (5):501-522. https://doi.org/10.1080/1747423X.2015.1117530

Meyfroidt, P., K. M. Carlson, M. E. Fagan, V. H. Gutiérrez-Vélez, M. N. Macedo, L. M. Curran, R. S. DeFries, G. A. Dyer, H. K. Gibbs, E. F. Lambin, D. C. Morton, and V. Robiglio. 2014. Multiple pathways of commodity crop expansion in tropical forest landscapes. Environmental Research Letters 9(7):074012. https://doi.org/10.1088/1748-9326/9/7/074012

Meyfroidt, P., R. Chowdhury, A. de Bremond, E. C. Ellis, K.-H. Erb, T. Filatova, R. D. Garrett, J. M. Grove, A. Heinimann, T. Kuemmerle, C. A. Kull, E. F. Lambin, Y. Landon, Y. le Polain de Waroux, P. Messerli, D. Müller, J. Ø. Nielsen, G. D. Peterson, V. Rodriguez García, M. Schlüter, B. L. Turner, II, and P. H. Verburg. 2018. Middle-range theories of land system change. Global Environmental Change 53:52-67. https://doi.org/10.1016/j. gloenvcha.2018.08.006

Milne, S. 2015. Cambodia's unofficial regime of extraction: illicit logging in the shadow of transnational governance and investment. Critical Asian Studies 47(2, SI):200-228. https://doi. org/10.1080/14672715.2015.1041275

Morse, J. M. 1991. Approaches to qualitative-quantitative methodological triangulation. Nursing Research 40(2):120-123. https://doi.org/10.1097/00006199-199103000-00014

Neef, A., S. Touch, and J. Chiengthong. 2013. The politics and ethics of land concessions in Rural Cambodia. Journal of Agricultural and Environmental Ethics 26(6):1085-1103. https:// doi.org/10.1007/s10806-013-9446-y

Oak Ridge National Laboratory (ORNL). 2017. LandScan population. Oak Ridge National Laboratory, Oak Ridge, Tennessee, USA. [online] URL: http://web.ornl.gov/sci/ landscan/.

Oberlack, C., D. Sietz, E. Bürgi Bonanomi, A. de Bremond, J. Dell'Angelo, K. Eisenack, E. C. Ellis, G. Epstein, M. Giger, A. Heinimann, C. Kimmich, M. T. J. Kok, D. Manuel-Navarrete, P. Messerli, P. Meyfroidt, T. Václavík, and S. Villamayor-Tomás. 2019. Archetype analysis in sustainability research: meanings, motivations, and evidence-based policy making. Ecology and Society XX(YY):ZZ.

Oberlack, C., L. Tejada, P. Messerli, S. Rist, and M. Giger. 2016. Sustainable livelihoods in the global land rush? Archetypes of livelihood vulnerability and sustainability potentials. Global Environmental Change 41:153-171. https://doi.org/10.1016/j. gloenvcha.2016.10.001

Oldenburg, C., and A. Neef. 2014. Reversing land grabs or aggravating tenure insecurity? Competing perspectives on economic land concessions and land titling in Cambodia. Law and Development Review 7(1):49-77. https://doi.org/10.1515/ 1dr-2014-0014

Oliveira, G. de L. T. 2016. The geopolitics of Brazilian soybeans. Journal of Peasant Studies 43(2):348-372. https://doi. org/10.1080/03066150.2014.992337 
Open Development Cambodia (ODC). 2018. Open Development Cambodia. Open Development Cambodia, Phnom Penh, Cambodia. [online] URL: http://opendevelopmentcambodia.net

Ordway, E. M., G. P. Asner, and E. F. Lambin. 2017. Deforestation risk due to commodity crop expansion in sub-Saharan Africa. Environmental Research Letters 12(4):044015. https://doi. org/10.1088/1748-9326/aa6509

Özdoğan, M., I. G. Baird, and M. B. Dwyer. 2018. The role of remote sensing for understanding large-scale rubber concession expansion in. Land 7(2):55. https://doi.org/10.3390/land7020055

Ragin, C. C., and S. Davey. 2016. Fuzzy-set/qualitative comparative analysis 3.0. Department of Sociology, University of California, Irvine, California, USA. [online] URL: http://www. socsci.uci.edu/ cragin/fsQCA/software.shtml

Rihoux, B., and C. C. Ragin. 2009. Configurational comparative methods: qualitative comparative analysis (QCA) and related techniques. Applied Social Research Methods Series, vol. 51. Sage, Thousand Oak, California, USA. https://doi.org/10.4135/9781452226569

Rindfuss, R. R., S. J. Walsh, B. L. Turner, II, J. Fox, and V. Mishra. 2004. Developing a science of land change: challenges and methodological issues. Proceedings of the National Academy of Sciences 101(39):13976-13981. https://doi.org/10.1073/pnas.0401545101

Rosenbaum, P. R., and D. B. Rubin. 1983. The central role of the propensity score in observational studies for causal effects. Biometrika 70(1):41-55. https://doi.org/10.21236/ADA114514

Royal Government of Cambodia (RGC). 2005. Sub-decree on economic land concessions. Royal Government of Cambodia, Phnom Penh, Cambodia. [online] URL: http://faolex.fao.org/ docs/texts/cam134075.doc

Rudel, T. K. 2008. Meta-analyses of case studies: a method for studying regional and global environmental change. Global Environmental Change 18(1):18-25. https://doi.org/10.1016/j. gloenvcha.2007.06.001

Rulli, M. C., A. Saviori, and P. D'Odorico. 2013. Global land and water grabbing. Proceedings of the National Academy of Sciences 110(3):892-897. https://doi.org/10.1073/pnas.1213163110

Runyan, C. W., P. D’Odorico, and D. Lawrence. 2012. Physical and biological feedbacks of deforestation. Reviews of Geophysics 50(4):RG4006. https://doi.org/10.1029/2012RG000394

Scheidel, A., M. Giampietro, and J. Ramos-Martin. 2013. Selfsufficiency or surplus: conflicting local and national rural development goals in Cambodia. Land Use Policy 34:342-352. https://doi.org/10.1016/j.landusepol.2013.04.009

Schmill, M. D., L. M. Gordon, N. R. Magliocca, E. C. Ellis, and T. Oates. 2014. GLOBE: analytics for assessing global representativeness. Pages 25-32 in Fifth international conference on computing for geospatial research and application. IEEE, New York, New York, USA. https://doi.org/10.1109/COM.Geo.2014.21

Schneider, C. Q., and C. Wagemann. 2010. Standards of good practice in qualitative comparative analysis (QCA) and fuzzy-sets. Comparative Sociology 9(3):397-418. https://doi. org/10.1163/156913210X12493538729793
Schönweger, O., A. Heinimann, M. Epprecht, J. Lu, P. Thalongsengchanh, and G. Bernensia. 2012. Concessions and leases in the Lao PDR: taking stock of land investments. Center for Development and Environment (CDE), University of Bern, Bern, Switzerland

Scoones, I., R. Hall, S. M. Borras, Jr., B. White, and W. Wolford. 2013. The politics of evidence: methodologies for understanding the global land rush. Journal of Peasant Studies 40(3):469-483. https://doi.org/10.1080/03066150.2013.801341

Seekell, D., J. Carr, J. Dell'Angelo, P. D’Odorico, M. Fader, J. Gephart, M. Kummu, N. Magliocca, M. Porkka, M. Puma, Z. Ratajczak, M. C. Rulli, S. Suweis, and A. Tavoni. 2017. Resilience in the global food system. Environmental Research Letters 12(2). https://doi.org/10.1088/1748-9326/aa5730

Senge, P. M. 1990. The new paradigm in business: emerging strategies for leadership and organizational change. Pages 126-138 in P. Senge, editor. The fifth discipline: the art and practice of the learning organization. Doubleday, New York, New York, USA.

Sietz, D. 2014. Regionalisation of global insights into dryland vulnerability: better reflecting smallholders' vulnerability in Northeast Brazil. Global Environmental Change 25:173-185. https://doi.org/10.1016/j.gloenvcha.2014.01.010

Sietz, D., U. Frey, M. Roggero, Y. Gong, N. R. Magliocca, R. Tan, P. Janssen, and T. Vaclavik. (this issue). Archetype analysis in sustainability research: Methodological challenges, potentials and analytical frontiers. Ecology and Society.

Subedi, S. P. 2012. A human rights analysis of economic and other land concessions in Cambodia: report of the special rapporteur on the situation of human rights in Cambodia. United Nations, New York, New York, USA. [online] URL: https://cambodia.ohchr. org/ cambodiaohchr/sites/default/files/news/WebDOCs/2012/ SR_report_on_ELC Eng.pdf

Thiem, A., and A. Duşa. 2013. QCA: a package for qualitative comparative analysis. $R$ Journal 5(1):87-97. https://doi. org/10.32614/RJ-2013-009

Thomas, J., A. O’Mara-Eves, and G. Brunton. 2014. Using qualitative comparative analysis (QCA) in systematic reviews of complex interventions: a worked example. Systematic Reviews 3 (1):67. https://doi.org/10.1186/2046-4053-3-67

United States National Aeronautics and Space Administration (NASA) and the Ministry of Economy, Trade, and Industry of Japan (METI). 2011. ASTGTM: ASTER global digital elevation model V002. NASA, Washington, D.C., USA. [online] URL: https://1pdaac.usgs.gov/products/astgtmv002/

Václavík, T., S. Lautenbach, T. Kuemmerle, and R. Seppelt. 2013. Mapping global land system archetypes. Global Environmental Change 23(6):1637-1647. https://doi.org/10.1016/j.gloenvcha.2013.09.004

Vance, C., and J. Geoghegan. 2002. Temporal and spatial modelling of tropical deforestation: a survival analysis linking satellite and household survey data. Agricultural Economics 27 (3):317-332. https://doi.org/10.1111/j.1574-0862.2002.tb00123.x

Vandergeten, E., A. Hossein, D. Teklemariam, J. Nyssen, F. Witlox, and E. Vanhaute. 2016. Agricultural outsourcing or land 
grabbing: a meta-analysis. Landscape Ecology 31(7):1395-1417. https://doi.org/10.1007/s10980-016-0365-y

Verburg, P. H., E. C. Ellis, and A. Letourneau. 2011. A global assessment of market accessibility and market influence for global environmental change studies. Environmental Research Letters 6 (3):034019. https://doi.org/10.1088/1748-9326/6/3/034019

Verkoren, W., and C. Ngin. 2017. Organizing against land grabbing in Cambodia: exploring missing links. Development and Change 48(6):1336-1361. https://doi.org/10.1111/dech.12346

van Vliet, J., N. R. Magliocca, B. Büchner, E. Cook, J. M. Rey Benayas, E. C. Ellis, A. Heinimann, E. Keys, T. M. Lee, J. Liu, O. Mertz, P. Meyfroidt, M. Moritz, C. Poeplau, B. E. Robinson, R. Seppelt, K. C. Seto, and P. H. Verburg. 2016. Meta-studies in land use science: current coverage and prospects. Ambio 45(1):15-28. https://doi.org/10.1007/s13280-015-0699-8

Wadhwa, M., and M. P. S. Bakshi. 2013. Utilization of fruit and vegetable wastes as livestock feed and as substrates for generation of other value-added products. FAO, Rome, Italy. [online] URL: http://www.fao.org/3/i3273e/i3273e.pdf

Wang, N., D. G. Brown, L. An, S. Yang, and A. LigmannZielinska. 2013. Comparative performance of logistic regression and survival analysis for detecting spatial predictors of land-use change. International Journal of Geographical Information Science 27(10):1960-1982. https://doi.org/10.1080/13658816.2013.779377

Wolstenholme, E. F. 2003. Towards the definition and use of a core set of archetypal structures in system dynamics. System Dynamics Review 19(1):7-26. https://doi.org/10.1002/sdr.259

Wolstenholme, E. 2004. Using generic system archetypes to support thinking and modelling. System Dynamics Review 20 (4):341-356. https://doi.org/10.1002/sdr.302

Zoomers, A. 2010. Globalisation and the foreignisation of space: seven processes driving the current global land grab. Journal of Peasant Studies 37(2):429-447. https://doi.org/10.1080/03066151003595325 
Appendix 1. Supporting methods and results.

\section{A1.1. Matching method}

Comparison of median standardized bias (MSB) between covariate matching using Mahalanobis distance versus propensity scores.

Table A1.1.1: Comparison of median standardized bias (MSB) between propensity score and covariate matching using Mahalanobis distance. Standardized bias is the absolute value of the difference of means in the treated and matched control subsamples as a percentage of the square root of the average sample variance in both groups. See Table 1 for variable definitions.

\begin{tabular}{ccccccc}
\hline Matching Estimator & Rice ratio & $\begin{array}{c}\text { Log avg. } \\
\text { slope }\end{array}$ & $\begin{array}{c}\text { \% tree cover } \\
(2000)\end{array}$ & $\begin{array}{c}\text { Log avg. mkt. } \\
\text { influence }\end{array}$ & $\begin{array}{c}\text { Log avg. pop. } \\
\text { density (2000) }\end{array}$ & Median \\
\hline $\begin{array}{c}\text { Mahalanobis } \\
\text { distance }\end{array}$ & 0.5266 & 0.5811 & 0.2228 & 0.0728 & 0.0048 & $\mathbf{0 . 2 2 2 8}$ \\
$\begin{array}{c}\text { Propensity score } \\
0.0974\end{array}$ & 0.0583 & 0.0407 & 0.0262 & 0.0727 & $\mathbf{0 . 0 5 8 3}$ \\
\hline
\end{tabular}

\section{A1.2. Bias balance}

Bias balance assessment among treated and untreated communes, and among matched pair stratifications.

Table A1.2.1. Covariate means for treatment and control group before and after propensity score matching

\begin{tabular}{|l|c|c|c|c|c|c|c|c|c|c|}
\hline & \multicolumn{2}{|c|}{ Rice ratio } & \multicolumn{2}{c|}{ Log avg. slope } & \multicolumn{2}{c|}{$\begin{array}{c}\text { \% tree cover } \\
(2000)\end{array}$} & \multicolumn{2}{c|}{$\begin{array}{c}\text { Log avg. mkt. } \\
\text { influence }\end{array}$} & \multicolumn{2}{c|}{$\begin{array}{c}\text { Log avg. pop. } \\
\text { density (2000) }\end{array}$} \\
\hline Group & $\mathrm{T}$ & $\mathrm{C}$ & $\mathrm{T}$ & $\mathrm{C}$ & $\mathrm{T}$ & $\mathrm{C}$ & $\mathrm{T}$ & $\mathrm{C}$ & $\mathrm{T}$ & $\mathrm{C}$ \\
\hline Unmatched & 29.02 & 48.99 & 1.60 & 1.40 & 40.20 & 42.49 & 6.7315 & 6.8958 & 4.6702 & 4.8558 \\
\hline Matched & 29.02 & 31.45 & 1.60 & 1.5779 & 40.20 & 41.13 & 6.7315 & 6.7018 & 4.6702 & 4.5982 \\
\hline
\end{tabular}

Table A1.2.2. Stratification balance based on ELC crop group* between matched treatment and control communes

\begin{tabular}{|l|c|c|c|c|c|c|c|c|c|c|}
\hline & \multicolumn{2}{|c|}{ Rice ratio } & \multicolumn{2}{c|}{ Log avg. slope } & \multicolumn{2}{c|}{ \% tree cover (2000) } & \multicolumn{2}{c|}{$\begin{array}{c}\text { Log avg. mkt. } \\
\text { influence }\end{array}$} & \multicolumn{2}{c|}{$\begin{array}{c}\text { Log avg. pop. } \\
\text { density (2000) }\end{array}$} \\
\hline Group & $\mathrm{T}$ & $\mathrm{C}$ & $\mathrm{T}$ & $\mathrm{C}$ & $\mathrm{T}$ & $\mathrm{C}$ & $\mathrm{T}$ & $\mathrm{C}$ & $\mathrm{T}$ & $\mathrm{C}$ \\
\hline Crop 1 & 23.85 & 23.54 & 1.68 & 1.59 & 39.10 & 45.02 & 6.3081 & 6.1402 & 4.33 & 4.23 \\
\hline Crop 2 & 38.07 & 34.01 & 1.48 & 1.44 & 36.89 & 35.02 & 7.0581 & 6.9271 & 5.19 & 5.03 \\
\hline Crop 3 & 27.35 & 34.88 & 1.61 & 1.64 & 42.60 & 42.02 & 6.8146 & 6.9218 & 4.60 & 4.83 \\
\hline
\end{tabular}

* Crop group: 1 = rubber; 2 = cassava, oil palm, sugar, cashew, teak; 3 = unknown

** No statistically significant differences among treatment and control means 
Table A1.2.3. Stratification balance based on rate of ELC land conversion between matched treatment and control communes

\begin{tabular}{|l|c|c|c|c|c|c|c|c|c|c|}
\hline & \multicolumn{2}{|c|}{ Rice Ratio } & \multicolumn{2}{c|}{ Log avg. slope } & \multicolumn{2}{c|}{$\begin{array}{c}\text { \% tree cover } \\
(2000)\end{array}$} & \multicolumn{3}{c|}{$\begin{array}{c}\text { Log avg. mkt. } \\
\text { influence }\end{array}$} & \multicolumn{2}{c|}{$\begin{array}{c}\text { Log avg. pop. } \\
\text { density (2000) }\end{array}$} \\
\hline Group & $\mathrm{T}$ & $\mathrm{C}$ & $\mathrm{T}$ & $\mathrm{C}$ & $\mathrm{T}$ & $\mathrm{C}$ & $\mathrm{T}$ & $\mathrm{C}$ & $\mathrm{T}$ & $\mathrm{C}$ \\
\hline Rapid & 24.90 & 26.90 & 1.66 & 1.63 & 43.06 & 38.72 & 6.64 & 6.47 & 4.68 & 4.51 \\
\hline $\begin{array}{l}\text { Gradual or } \\
\text { No Change }\end{array}$ & 30.87 & 33.50 & 1.567 & 1.56 & 38.91 & 42.22 & 6.78 & 6.81 & 4.67 & 4.64 \\
\hline
\end{tabular}

** No statistically significant differences among treatment and control means

Table A1.2.4. Stratification balance based on \% of province land area in ELC between matched treatment and control communes

\begin{tabular}{|l|c|c|c|c|c|c|c|c|c|c|}
\hline & \multicolumn{2}{|c|}{$\begin{array}{c}\text { Commune size } \\
\text { (ha) }\end{array}$} & \multicolumn{2}{c|}{ Log avg. slope } & \multicolumn{2}{c|}{ \% tree cover (2000) } & \multicolumn{2}{c|}{$\begin{array}{c}\text { Log avg. mkt. } \\
\text { influence }\end{array}$} & \multicolumn{2}{c|}{$\begin{array}{c}\text { Log avg. pop. } \\
\text { density (2000) }\end{array}$} \\
\hline Group & $\mathrm{T}$ & $\mathrm{C}$ & $\mathrm{T}$ & $\mathrm{C}$ & $\mathrm{T}$ & $\mathrm{C}$ & $\mathrm{T}$ & $\mathrm{C}$ & $\mathrm{T}$ & $\mathrm{C}$ \\
\hline$<11 \%$ & 28.45 & 37.50 & 1.5884 & 1.6472 & 29.6304 & 24.1971 & 7.2099 & 7.2282 & 4.6751 & 4.7972 \\
\hline $11-20 \%$ & 31.41 & 28.47 & 1.5884 & 1.4998 & 41.2949 & 44.5637 & 6.4219 & 6.3725 & 4.6785 & 4.4872 \\
\hline$>20 \%$ & 26.23 & 30.36 & 1.6105 & 1.6256 & 47.7489 & 50.9500 & 6.7460 & 6.7022 & 4.6544 & 4.5800 \\
\hline
\end{tabular}

** No statistically significant differences among treatment and control means

\section{A1.3. Matching sensitivity analysis}

Rosenbaum bounds were calculated using the R package 'rbounds' (Keele 2010) to check for sensitivity of results to unobserved factors that might bias selection into the treatment group (Rosenbaum and Rubin 1983, DiPrete and Gangl 2004, Blackman et al. 2015). Specifically, we used the Rosenbaum procedure adapted for binary outcomes with the test statistic, $\Gamma$, ranging from 1.0 to 2.0. Results for national-level matching analysis showed a critical value, $\Gamma^{*}$, above which the results for ATT would no longer be significant at the 5 percent level, of 1.3. In other words, our findings would remain significant with matched pairs differing in their odds of treatment by $30 \%$. Given the likely level of unobserved heterogeneity in a national-level analysis, and combined with a balanced stratification, this is a satisfactory level of sensitivity from which to make preliminary inferences.

Table A1.3.1. Rosenbaum sensitivity analysis results.

\begin{tabular}{|c|c|c|}
\hline \multicolumn{2}{|l|}{ Unconfounded p-value estimate } & 0.0036 \\
\hline Gamma & Lower Bound & Upper Bound \\
\hline 1.0 & 0.00364 & 0.00364 \\
\hline 1.1 & 0.00093 & 0.01199 \\
\hline 1.2 & 0.00023 & 0.03077 \\
\hline 1.3 & 0.00006 & 0.06501 \\
\hline 1.4 & 0.00001 & 0.11775 \\
\hline 1.5 & 0.00000 & 0.18870 \\
\hline 1.6 & 0.00000 & 0.27423 \\
\hline 1.7 & 0.00000 & 0.36845 \\
\hline 1.8 & 0.00000 & 0.46483 \\
\hline 1.9 & 0.00000 & 0.55757 \\
\hline 2.0 & 0.00000 & 0.64234 \\
\hline $\begin{array}{l}\text { Note: Gamma is odds of differential assignment to } \\
\text { treatment due to unobserved factors }\end{array}$ \\
\hline \multicolumn{2}{|l}{} \\
\hline
\end{tabular}




\section{A1.4. Representativeness assessment}

Comparison of distributions of empirical and case study samples for crop type, percent forest cover, .... The number of expected cases was given by multiplying the probability of ELC records per category or percentile by the total sample size of cases derived from case study synthesis. Because of the small sample size (30) and possibility of zero observed cases, Fisher's Exact Test was used to assess whether the observed number of cases was statistically significantly different from the empirical probability of ELC records per category or percentile. Contingency tables were calculated by comparing the expected and observed frequencies of cases for a given category or percentile versus all other categories or percentiles. The null hypothesis was that there are no non-random differences in the distributions of observed and expected values.

Table A1.4.1. Crop Type

\begin{tabular}{|c|c|c|c|c|}
\hline Crop Type & Expected & Observed & Reject $\mathbf{H}_{\mathbf{0}}$ & p-value \\
\hline Rubber & 15.3363 & 12 & 0 & 0.6042 \\
\hline Cassava & 0.9417 & 1 & 0 & 1.0000 \\
\hline Sugarcane & 2.0179 & 5 & 0 & 0.4238 \\
\hline Cashew & 0.8072 & 0 & 0 & 1.0000 \\
\hline Oil Palm & 0.6726 & 0 & 0 & 1.0000 \\
\hline Teak & 0.8072 & 3 & 0 & 0.6120 \\
\hline Other or Unspecified & 9.4170 & 9 & 0 & 1.0000 \\
\hline
\end{tabular}

Table A1.4.2. Percent forest cover in 2000

\begin{tabular}{|c|c|c|c|c|}
\hline \% Forest Cover & Expected & Observed & Reject $\mathbf{H}_{\mathbf{0}}$ & p-value \\
\hline $0-10$ & 1.3453 & 2 & 0 & 1.0000 \\
\hline $11-20$ & 2.4215 & 2 & 0 & 1.0000 \\
\hline $21-30$ & 2.8251 & 2 & 0 & 0.6707 \\
\hline $31-40$ & 3.0942 & 2 & 0 & 0.6707 \\
\hline $41-50$ & 3.9013 & 4 & 0 & 1.0000 \\
\hline $51-60$ & 3.3632 & 6 & 0 & 0.4716 \\
\hline $61-70$ & 2.6906 & 2 & 0 & 0.6707 \\
\hline $71-80$ & 2.5561 & 1 & 0 & 0.3533 \\
\hline $81-90$ & 5.3812 & 4 & 0 & 0.7306 \\
\hline $91-100$ & 2.4215 & 5 & 0 & 0.4238 \\
\hline
\end{tabular}


Table A1.4.3. Population Density

\begin{tabular}{|c|c|c|c|c|}
\hline Log Pop. Density & Expected & Observed & Reject $\mathbf{H}_{\mathbf{0}}$ & p-value \\
\hline $0.5-1.029$ & 2.1525 & 3 & 0 & 1.0000 \\
\hline $1.030-1.559$ & 2.6906 & 1 & 0 & 0.6120 \\
\hline $1.560-2.089$ & 4.7085 & 4 & 0 & 1.0000 \\
\hline $2.090-2.619$ & 4.7085 & 3 & 0 & 0.7065 \\
\hline $2.620-3.149$ & 7.1300 & 4 & 0 & 0.5062 \\
\hline $3.150-3.679$ & 3.3632 & 5 & 0 & 0.7065 \\
\hline $3.680-4.209$ & 1.7489 & 5 & 0 & 0.4238 \\
\hline $4.210-4.739$ & 1.4798 & 4 & 0 & 0.3533 \\
\hline $4.740-5.269$ & 1.6143 & 0 & 0 & 0.4915 \\
\hline $5.270-5.800$ & 0.4036 & 1 & 0 & 1.0000 \\
\hline
\end{tabular}

Table A1.4.4. Market Price 2008

Market price for natural rubber was estimated by interacting global commodity price in 2008 with a market influence index (Verburg et al. 2011).

\begin{tabular}{|c|c|c|c|c|}
\hline Market Price & Expected & Observed & Reject $\mathrm{H}_{0}$ & $\mathrm{p}$-value \\
\hline-7.200 to -6.201 & 1.8834 & 3 & 0 & 1.0000 \\
\hline-6.200 to -5.201 & 0.8072 & 1 & 0 & 1.0000 \\
\hline-5.200 to -4.201 & 1.0762 & 1 & 0 & 1.0000 \\
\hline-4.200 to -3.201 & 1.4798 & 0 & 0 & 1.0000 \\
\hline-3.200 to -2.201 & 4.8430 & 4 & 0 & 1.0000 \\
\hline-2.200 to -1.201 & 2.9596 & 1 & 0 & 0.6120 \\
\hline-1.200 to -0.201 & 4.3049 & 3 & 0 & 1.0000 \\
\hline-0.200 to 0.799 & 6.5919 & 4 & 0 & 0.5062 \\
\hline-1.200 to 0.799 & 4.4395 & 6 & 0 & 0.7306 \\
\hline 1.800 to 2.800 & 1.6143 & 7 & 0 & 0.1455 \\
\hline
\end{tabular}




\section{A1.5. Qualitative comparative analysis}

Table A1.5.1. Lists of candidate causal conditions of indirect land use change (iLUC)

\begin{tabular}{|c|c|c|c|c|}
\hline \multirow[t]{2}{*}{ Causal conditions } & \multirow[t]{2}{*}{ Type variable } & \multirow{2}{*}{$\begin{array}{l}\text { Sub- } \\
\text { category }\end{array}$} & \multicolumn{2}{|l|}{ Operationalization } \\
\hline & & & Description/justification & $\begin{array}{l}\text { Fuzzy } \\
\text { membership } \\
\text { score }\end{array}$ \\
\hline $\begin{array}{l}\text { Land use change } \\
\text { rate }\end{array}$ & Contextual & Rapid & $\begin{array}{l}\text { Rate of land change }<=2 \text { years or described in source as rapid, unexpected, or } \\
\text { surprising. }\end{array}$ & 1 \\
\hline \multirow[t]{2}{*}{ (LCRATE) } & & Gradual & $\begin{array}{l}\text { Rate of land change }>2 \text { years or described in source as gradual or occurring in } \\
\text { multiple phases over time. }\end{array}$ & 0 \\
\hline & & None & Confirmation of no land change reported in source & 0 \\
\hline \multirow[t]{2}{*}{$\begin{array}{l}\text { Compensation } \\
\text { (COMP) }\end{array}$} & Contextual & Yes & $\begin{array}{l}\text { Some form of individual compensation described, for example monetary or land } \\
\text { exchange }\end{array}$ & 1 \\
\hline & & No & No information described & 0 \\
\hline \multirow{3}{*}{$\begin{array}{l}\text { Employment } \\
\text { (EMP) }\end{array}$} & Contextual & Full & Local community members employed in activities related to LSLA & 1 \\
\hline & & Partial & $\begin{array}{l}\text { Only some local community members employed due to insufficient employment } \\
\text { opportunities, competition from immigrants, or by choice as form of resistance. }\end{array}$ & 0 \\
\hline & & None & No employment opportunities offered through LSLA & 0 \\
\hline \multirow[t]{2}{*}{$\begin{array}{l}\text { Displacement } \\
\text { (DISP) }\end{array}$} & Casual & Yes & $\begin{array}{l}\text { Description of community displacement and/or out-migration resulting from } \\
\text { LSLA }\end{array}$ & 1 \\
\hline & & No & No information described & 0 \\
\hline \multirow{4}{*}{$\begin{array}{l}\text { Rubber } \\
\text { (TREE) } \\
\text { Immigration } \\
\text { (IMM) }\end{array}$} & Casual & Yes & LSLA with the presence of rubber & 1 \\
\hline & & No & Otherwise & 0 \\
\hline & Casual & Yes & LSLA has resulted in in-migration, usually from migrants seeking employment & 1 \\
\hline & & No & No information described & 0 \\
\hline \multirow[t]{3}{*}{$\begin{array}{l}\text { Conflict } \\
\text { (CONF) }\end{array}$} & Contextual & Direct & $\begin{array}{l}\text { Evidence of direct confrontation between ELC and community. Examples include } \\
\text { reported land disputes (LICAHDO), re-taking or stopping use of LSLA land through } \\
\text { force or threat of force }\end{array}$ & 1 \\
\hline & & Indirect & $\begin{array}{l}\text { Evidence of political, legal, or otherwise non-physical contestation of ELC by } \\
\text { community members. For example, a more conflictual livelihood context } \\
\text { (Oberlack et al., 2016), contested compensation, political advocacy }\end{array}$ & 0.5 \\
\hline & & Both & Some combination of direct and indirect conflict & 1 \\
\hline
\end{tabular}


Table A1.5.2. Lists of cases associated with attributes and causal multiple-pathways

\begin{tabular}{|c|c|c|c|c|c|c|c|c|c|c|c|c|c|c|c|c|}
\hline \multirow{2}{*}{ \# } & \multirow{2}{*}{$\begin{array}{c}\text { Case } \\
\text { ID }\end{array}$} & \multirow{2}{*}{$\begin{array}{c}\text { Cartodb } \\
\text { ID }\end{array}$} & \multirow{2}{*}{$\begin{array}{l}\text { Deal } \\
\text { Year }\end{array}$} & \multirow[b]{2}{*}{ Location } & \multirow[b]{2}{*}{ Sources } & \multicolumn{7}{|c|}{ Candidate focus conditions } & \multicolumn{3}{|c|}{ Outcome conditions } & \multirow[t]{2}{*}{ Pathways ${ }^{7.5}$} \\
\hline & & & & & & LCRATE & EMP & CONF & TREE & COMP & DISP & IMM & iLUC ${ }^{10}$ & iLUC ${ }^{7.5}$ & iLUC $^{5}$ & \\
\hline 1 & 36 & 36 & 2011 & Ta Veng District; Ratanakiri Province & Baird, I. G. (2017) & 1 & 0 & 1 & 1 & 0 & 0 & 0 & 0 & 0 & 0 & LCRATE*TREE* EMP* DISP* IMM*CONF \\
\hline 2 & 110 & 110 & 2012 & Veun Sai District; Ratanakiri Province & Baird, I. G. (2017) & 0 & 0 & 1 & 1 & 0 & 0 & 0 & 0 & 0 & 0 & $\sim$ LCRATE*TREE* COMP* EMP* DISP* IMM*CONF \\
\hline 3 & 168 & 168 & 2000 & $\begin{array}{l}\text { Boriboor; leuk Phoss;Samaki } \\
\text { Meanchey;Krakor Districts; Kampong } \\
\text { Chhnang and Pursat Provinces }\end{array}$ & $\begin{array}{l}\text { Beban, A., So, S. and Un, K. } \\
\text { (2017) }\end{array}$ & 0 & 0 & 0.5 & 0 & 0 & 1 & 0 & 1 & 1 & 1 & $\mathrm{NP}$ \\
\hline 4 & 15 & 15 & 2000 & Preah Sihanouk Province & $\begin{array}{l}\text { Beban, A., So, S. and Un, K. } \\
\text { (2017) }\end{array}$ & 0 & 0 & 0 & 0 & 1 & 1 & 0 & 1 & 1 & 1 & $\sim$ LCRATE* TREE*COMP* EMP*DISP* IMM ${ }^{* \sim}$ CONF \\
\hline 5 & 151 & 151 & 2006 & $\begin{array}{l}\text { Beng Commune; Sre Ambel District; } \\
\text { Koh Kong Province }\end{array}$ & $\begin{array}{l}\text { Dwyer, M. B. (2015); } \\
\text { Bristol, G. (2007) }\end{array}$ & 1 & 1 & 1 & 0 & 1 & 0 & 0 & 0 & 0 & 0 & LCRATE* TREE*COMP*EMP* DISP* IMM ${ }^{*}$ CONF \\
\hline 6 & 152 & 152 & 2006 & $\begin{array}{l}\text { Botum Sakor District; Koh Kong } \\
\text { Province }\end{array}$ & $\begin{array}{l}\text { Dwyer, M. B. (2015); } \\
\text { Bristol, G. (2007) }\end{array}$ & 1 & 1 & 1 & 0 & 1 & 0 & 0 & 0 & 0 & 0 & LCRATE* TREE*COMP*EMP* DISP* IMM ${ }^{*}$ CONF \\
\hline 7 & 138 & 138 & 2006 & $\begin{array}{l}\text { Kbal Damrey Commune; Kratie } \\
\text { Province }\end{array}$ & $\begin{array}{l}\text { Neef, A., Touch, S., \& } \\
\text { Chiengthong, J. (2013) }\end{array}$ & 1 & 1 & 0.5 & 0 & 0 & 0 & 0 & 1 & 1 & 1 & $\mathrm{NP}$ \\
\hline 8 & 135 & 135 & 2006 & $\begin{array}{l}\text { Kbal Damrey Commune; Kratie } \\
\text { Province }\end{array}$ & $\begin{array}{l}\text { Neef, A., Touch, S., \& } \\
\text { Chiengthong, J. (2013) }\end{array}$ & 1 & 1 & 0.5 & 0 & 0 & 0 & 0 & 0 & 0 & 1 & NP \\
\hline 9 & 128 & 128 & 2006 & $\begin{array}{l}\text { Kbal Damrey Commune; Kratie } \\
\text { Province }\end{array}$ & $\begin{array}{l}\text { Neef, A., Touch, S., \& } \\
\text { Chiengthong, J. (2013) }\end{array}$ & 0 & 1 & 0.5 & 0 & 0 & 0 & 0 & 1 & 1 & 1 & NP \\
\hline 10 & 62 & 62 & 2005 & Sesan District; Stung Treng Province & Baird, I. G., \& Fox, J. (2015) & 1 & 1 & 0.5 & 1 & 1 & 0 & 1 & 1 & 1 & 1 & $\mathrm{NP}$ \\
\hline 11 & 162 & 162 & 2005 & Sesan District; Stung Treng Province & Baird, I. G., \& Fox, J. (2015) & 1 & 1 & 0.5 & 1 & 1 & 0 & 1 & 1 & 1 & 1 & NP \\
\hline 12 & 111 & 111 & 2009 & Veun Sai District; Ratanakiri Province & Baird, I. G., \& Fox, J. (2015) & 1 & 0 & 1 & 1 & 0 & 0 & 0 & 1 & 1 & 1 & LCRATE*TREE* EMP* DISP* IMM*CONF \\
\hline 13 & 278 & 278 & 2011 & Mondulkiri Province & Milne, S. (2015) & 1 & 0 & 1 & 1 & 0 & 0 & 0 & 1 & 1 & 1 & LCRATE*TREE* EMP** DISP* IMM"CONF \\
\hline 14 & 169 & 169 & 2011 & Kratie Province & Milne, S. (2015) & 0 & 0 & 0 & 1 & 0 & 0 & 0 & 1 & 1 & 1 & $\sim$ LCRATE*TREE* COMP* EMP* DISP* IMM ${ }^{* \sim}$ CONF \\
\hline 15 & 188 & 188 & 2007 & $\begin{array}{l}\text { Koum Choar Commune; O'Ya Dav } \\
\text { District; Ratanakiri Province }\end{array}$ & $\begin{array}{l}\text { Gironde, C., \& Peeters, A. } \\
\text { (2015, June) }\end{array}$ & 1 & 0 & 1 & 1 & 1 & 1 & 1 & 1 & 1 & 1 & LCRATE*TREE*COMP* EMP*DISP*CONF \\
\hline 16 & 87 & 87 & 2009 & $\begin{array}{l}\text { Malik Commune; Andoung Meas } \\
\text { District; Ratanakiri Province }\end{array}$ & $\begin{array}{l}\text { Gironde, C., \& Peeters, A. } \\
\text { (2015, June) }\end{array}$ & 1 & 0 & 1 & 1 & 1 & 1 & 1 & 1 & 1 & 1 & LCRATE*TREE*COMP* EMP*DISP*CONF \\
\hline 17 & 55 & 55 & 2011 & $\begin{array}{l}\text { Malik Commune; Andoung Meas } \\
\text { District; Ratanakiri Province }\end{array}$ & $\begin{array}{l}\text { Gironde, C., \& Peeters, A. } \\
\text { (2015, June) }\end{array}$ & 0 & 0 & 0.5 & 1 & 0 & 1 & 1 & 1 & 1 & 1 & NP \\
\hline 18 & 259 & 259 & 2011 & $\begin{array}{l}\text { Malik Commune; Andoung Meas } \\
\text { District; Ratanakiri Province }\end{array}$ & $\begin{array}{l}\text { Gironde, C., \& Peeters, A. } \\
\text { (2015, June) }\end{array}$ & 1 & 1 & 1 & 1 & 0 & 1 & 1 & 0 & 1 & 1 & LCRATE*TREE* ${ }^{*}$ COMP*EMP*DISP*IMM*CONF \\
\hline 19 & 18 & 18 & 2011 & $\begin{array}{l}\text { Khsem commune, Keio Seima district, } \\
\text { Kratie Province }\end{array}$ & $\begin{array}{l}\text { Lamb, V., Schoenberger, } \\
\text { L., Middleton, C., \& Un, B. } \\
\text { (2017) }\end{array}$ & 1 & 1 & 1 & 0 & 0 & 1 & 0 & 0 & 0 & 1 & LCRATE* TREE* COMP*EMP*DISP* IMM"CONF \\
\hline 20 & 156 & 156 & 2010 & $\begin{array}{l}\text { Omlaing commune, Oral district, } \\
\text { Kampong Speu Province }\end{array}$ & $\begin{array}{l}\text { Scheidel, A. (2016); EJatlas, } \\
\text { 2015a }\end{array}$ & 1 & 1 & 1 & 0 & 0 & 1 & 0 & 0 & 0 & 0 & LCRATE* TREE* COMP*EMP*DISP* IMM*CONF \\
\hline 21 & 22 & 22 & 2011 & $\begin{array}{l}\text { Omlaing commune, Oral district, } \\
\text { Kampong Speu Province }\end{array}$ & $\begin{array}{l}\text { Scheidel, A. (2016); EJatlas, } \\
\text { 2015a }\end{array}$ & 1 & 1 & 1 & 0 & 0 & 1 & 0 & 0 & 0 & 0 & LCRATE* TREE* COMP*EMP*DISP* IMM ${ }^{*}$ CONF \\
\hline 22 & 21 & 21 & 2010 & $\begin{array}{l}\text { Thpong district, Kamping Speu } \\
\text { province }\end{array}$ & $\begin{array}{l}\text { Scheidel, A. (2016); } \\
\text { EJatlas, 2015a }\end{array}$ & 0 & 0 & 1 & 0 & 0 & 1 & 0 & 1 & 1 & 1 & NP \\
\hline 23 & 154 & 154 & 2005 & $\begin{array}{l}\text { Trapang Phlang commune, Chhouk } \\
\text { district, Kampot province }\end{array}$ & $\begin{array}{l}\text { Scheidel, A. (2016); EJatlas, } \\
\text { 2015a }\end{array}$ & 1 & 0 & 1 & 1 & 0 & 0 & 0 & 1 & 1 & 1 & LCRATE*TREE* ${ }^{*}$ EMP* DISP* IMM ${ }^{*}$ CONF \\
\hline 24 & 253 & 253 & 2008 & $\begin{array}{l}\text { Khsuem commune, Snuol district, } \\
\text { Kratie Province }\end{array}$ & Schoenberger, L. (2017) & 1 & 0 & 1 & 1 & 1 & 0 & 0 & 1 & 1 & 1 & LCRATE*TREE* EMP ${ }^{*} \sim$ DISP* IMM*CONF \\
\hline 25 & 24 & 12 & 2010 & $\begin{array}{l}\text { Khsuem commune, Snuol district, } \\
\text { Kratie Province }\end{array}$ & Schoenberger, L. (2017) & 1 & 0 & 1 & 1 & 0 & 0 & 0 & 1 & 1 & 1 & LCRATE*TREE* EMP* DISP* IMM*CONF \\
\hline 26 & 155 & 153 & 2008 & Snoul district, Kratie province & Licadho. 2009 & 0 & 0 & 0.5 & 0 & 0 & 1 & 0 & 0 & 0 & 0 & NP \\
\hline 27 & 204 & 262 & 2005 & $\begin{array}{l}\text { Dak Dam commune, O Raing district, } \\
\text { Mondulkiri province }\end{array}$ & $\begin{array}{l}\text { Vize, J., and M; } \\
\text { Hornung. } 2013\end{array}$ & 1 & 1 & 1 & 0 & 1 & 1 & 1 & 1 & 1 & 1 & LCRATE* TREE*COMP*EMP*DISP*IMM*CONF \\
\hline 28 & 88 & 79 & 2008 & $\begin{array}{l}\text { Botum Sakor National Park; Koh Kong } \\
\text { Province }\end{array}$ & $\begin{array}{l}\text { Drbohlav, P., and J.; } \\
\text { Hejkrlik. 2018 } \\
\text { Perroulaz, G., C; }\end{array}$ & 1 & 0 & 1 & 1 & 1 & 1 & 0 & 1 & 1 & 1 & LCRATE*TREE*COMP* EMP*DISP*CONF \\
\hline 29 & 78 & 68 & 2008 & Campong Thom province & $\begin{array}{l}\text { Fioroni, and G. Carbonnier. } \\
2015\end{array}$ & 1 & 0 & 0.5 & 1 & 0 & 0 & 0 & 1 & 1 & 1 & NP \\
\hline 30 & 219 & 277 & 2011 & $\begin{array}{l}\text { Seda commune, Lumphat district, } \\
\text { Ratanakiri province }\end{array}$ & Chea, R. P. \& P. 2015 & 0 & 0 & 0.5 & 0 & 0 & 0 & 0 & 0 & 0 & 1 & NP \\
\hline
\end{tabular}

Note: * ${ }^{*}$ and, $\sim=$ absence of,$+=$ or; $\rightarrow=$ sufficient for; LCRATE = Land use change rate; EMP = employment; CONF = conflict; TREE = rubber; COMP = compensation; IMM = immigration; DISP = displacement. NP = no pathway; iLUC $C^{10}$, iLUC.5, iLUC ${ }^{5}$ present iLUC associated with the threshold value of the forest loss rate at $10 \%, 7.5 \%, 5 \%$, respectively; Pathways7.5 presents the pathway associated with either iLUC or the absence of iLUC at $7.5 \%$. Case ID = unique identifier linking ELCS reported in the case studies to the 
Table A1.5.3. Solution formula for iLUC and the absence of iLUC with sensitivity analysis

\begin{tabular}{|c|c|c|c|c|c|}
\hline Solution & $\begin{array}{l}\text { Justification \& } \\
\text { conditions }\end{array}$ & Solution formula & $\begin{array}{c}\text { Cases } \\
\text { Covered (Case ID) } \\
\end{array}$ & Con. & Cov. \\
\hline A1 & $\begin{array}{l}\text { Outcome condition iLUC } \\
\text { with a threshold value } \\
\text { of } 10 \%\end{array}$ & $\begin{array}{l}\text { LCRATE* CONF*(TREE* EMP* DISP* IMM + COMP*DISP } \\
(\text { TREE* EMP*DISP + TREE*EMP*IMM)) + } \\
\sim \text { LCRATE* IMM* CONF* EMP*(TREE* COMP* DISP + } \\
\sim \text { TREE*COMP*DISP }) \rightarrow \text { iLUC }\end{array}$ & $\begin{array}{r}36,111,278,154 \\
253,188,87 \\
88,169,15,204\end{array}$ & 0.920 & 0.605 \\
\hline A2 & $\begin{array}{l}\text { Outcome condition iLUC } \\
\text { with a threshold value } \\
\text { of } 7.5 \%\end{array}$ & $\begin{array}{l}\text { LCRATE* CONF*(TREE* }(\sim \text { EMP* DISP* IMM + COMP* EMP*DISP + } \\
\sim \text { COMP*EMP*DISP*IMM) + TREEE COMP*EMP*DISP*IMM) + } \\
\sim \text { LCRATE* EMP* IMM* CONF (TREE* COMP** DISP + } \\
\sim \text { LCRATE* TREE*COMP*DISP) } \rightarrow \text { iLUC }\end{array}$ & $\begin{array}{r}36,111,278,154 \\
253,188,87 \\
88,169,15,204 \\
259\end{array}$ & 0.926 & 0.625 \\
\hline A3 & $\begin{array}{l}\text { Outcome condition iLUC } \\
\text { with a threshold value } \\
\text { of } 5 \%\end{array}$ & $\begin{array}{l}\text { LCRATE* CONF*(TREE* }(\sim \text { EMP* DISP* IMM + COMP* EMP*DISP })+ \\
\sim \text { COMP*EMP*DISP*IMM + } \sim \text { TREE*COMP*EMP*DISP*IMM)) + } \\
\sim \text { LCRATE* EMP* } \sim \text { CONF* } \\
(\text { TREE* COMP * DISP* IMM + } \text { TREE*COMP*DISP* IMM) } \rightarrow \text { iLUC }\end{array}$ & $\begin{array}{r}36,111,278,154 \\
253,188,87 \\
88,169,15,204 \\
259\end{array}$ & 0.926 & 0.543 \\
\hline B1 & $\begin{array}{l}\text { Outcome condition, the } \\
\text { absence of iLUC with a } \\
\text { threshold value of } 10 \%\end{array}$ & $\begin{array}{l}\text { CONF*( DISP* IMM ( LCRATE*TREE* }{ }^{*} \text { COMP* EMP + } \\
\text { LCRATE* TREE*COMP*EMP) + } \\
\text { LCRATE* COMP*DISP*EMP*( TREE* IMM + *TREE*IMM) } \\
\rightarrow \text { no iLUC }\end{array}$ & $\begin{array}{r}110,151,152,18 \\
156,22,259\end{array}$ & 1 & 0.636 \\
\hline B2 & $\begin{array}{l}\text { Outcome condition, the } \\
\text { absence of iLUC with a } \\
\text { threshold value of } 7.5 \%\end{array}$ & $\begin{array}{l}\sim \text { IMM }^{*} \text { CONF*( LCRATE*TREE* COMP* EMP* DISP + } \\
\text { LCRATE* TREE* EMP*(COMP* DISP + CCOMP*DISP })) \\
\rightarrow \text { no iLUC }\end{array}$ & $\begin{array}{r}110,151,152,18 \\
156,22\end{array}$ & 1 & 0.6 \\
\hline B3 & $\begin{array}{l}\text { Outcome condition, the } \\
\text { absence of iLUC with a } \\
\text { threshold value of } 5 \%\end{array}$ & $\begin{array}{l}\sim \text { DISP* IMM }^{*} \text { CONF*( LCRATE*TREE } * \sim C O M P * \sim E M P ~+ \\
\text { LCRATE* TREE*COMP*EMP }) \rightarrow \text { no iLUC }\end{array}$ & $110,151,152$ & 1 & 0.429 \\
\hline
\end{tabular}

\section{References}

Blackman, A., A. Pfaff, and J. Robalino. 2015. Paper park performance: Mexico's natural protected areas in the 1990s. Global Environmental Change 31:50-61.

DiPrete, T. A., and M. Gangl. 2004. 7. Assessing Bias in the Estimation of Causal Effects: Rosenbaum Bounds on Matching Estimators and Instrumental Variables Estimation with Imperfect Instruments. Sociological Methodology 34(1):271-310.

Keele, L. 2010. An overview of rbounds: An R package for Rosenbaum bounds sensitivity analysis with matched data. White Paper. Columbus, $O H: 1-15$.

Rosenbaum, P. R., and D. B. Rubin. 1983. The central role of the propensity score in observational studies for causal effects. Biometrika 70(1):41-55.

Verburg, P. H., E. C. Ellis, and A. Letourneau. 2011. A global assessment of market accessibility and market influence for global environmental change studies. Environmental Research Letters 6(3):034019. 